
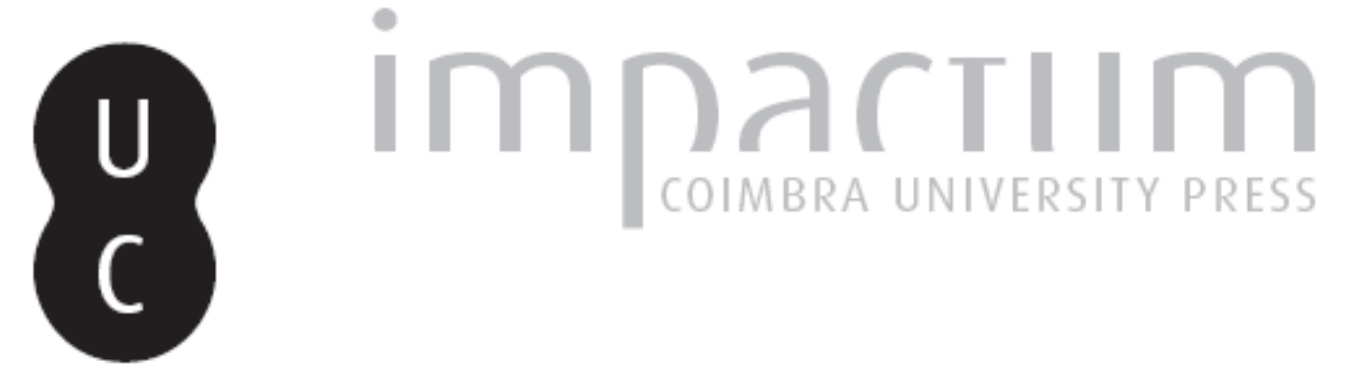

\title{
Plenas manifestações do risco de incêndio florestal em serras do Centro de Portugal: efeitos erosivos subsequentes e reabilitações pontuais
}
Autor(es):
Lourenço, Luciano
Publicado por: Associação Portuguesa de Riscos, Prevenção e Segurança
URL
persistente:
URI:http://hdl.handle.net/10316.2/36138
DOI:
DOI:http://dx.doi.org/10.14195/1647-7723_16_1
Accessed : $\quad$ 26-Apr-2023 16:17:34

A navegação consulta e descarregamento dos títulos inseridos nas Bibliotecas Digitais UC Digitalis, UC Pombalina e UC Impactum, pressupõem a aceitação plena e sem reservas dos Termos e Condições de Uso destas Bibliotecas Digitais, disponíveis em https://digitalis.uc.pt/pt-pt/termos.

Conforme exposto nos referidos Termos e Condições de Uso, o descarregamento de títulos de acesso restrito requer uma licença válida de autorização devendo o utilizador aceder ao(s) documento(s) a partir de um endereço de IP da instituição detentora da supramencionada licença.

Ao utilizador é apenas permitido o descarregamento para uso pessoal, pelo que o emprego do(s) título(s) descarregado(s) para outro fim, designadamente comercial, carece de autorização do respetivo autor ou editor da obra.

Na medida em que todas as obras da UC Digitalis se encontram protegidas pelo Código do Direito de Autor e Direitos Conexos e demais legislação aplicável, toda a cópia, parcial ou total, deste documento, nos casos em que é legalmente admitida, deverá conter ou fazer-se acompanhar por este aviso.

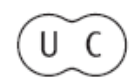




\section{territorium}

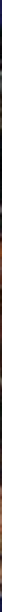

16

Revista da Associação Portuguesa de Riscos, Prevenção e Segurança 2009 


\section{PLENAS MANIFESTAÇÕES DO RISCO DE INCÊNDIO FLORESTAL EM SERRAS DO CENTRO DE PORTUGAL. EFEITOS EROSIVOS SUBSEQUENTES E REABILITAÇÕES PONTUAIS*}

Luciano Lourenço

NICIF - Núcleo de Investigação Científica de Incêndios Florestais Departamento de Geografia da Faculdade de Letras da Universidade de Coimbra lucianolafl.uc.pt

\section{RESUMO}

As serras do centro de Portugal têm sido frequentemente fustigadas por violentos incêndios florestais, razão porque tomámos como referência a do Açor, por esta apresentar uma das mais elevadas taxa de reincidência de incêndios florestais em Portugal.

De entre os vários incêndios que a têm assolado, na vertente Norte destacam-se, pela sua gravidade e pela dimensão da área afectada, as registados entre 13 e 20 de Setembro de 1987 e entre 19 e 24 de Julho de 2005, ambos com área ardida superior a 10000 hectares.

Por coincidência, uma parte da área queimada foi comum a ambos e, além disso, também nos dois casos, se verificaram episódios pluviosos de grande intensidade no ano imediatamente subsequente ao do incêndio florestal.

Assim, posteriormente às plenas manifestação do risco de incêndio, também vieram a ocorrer plenas manifestaçães do risco de erosão hídrica, umas e autras com graves consequências em termos de destruição de bens e, até, com perda de uma vida humana.

Este trabalho embora identifique algumas das áreas que foram afectadas, mais do que dar conta da destruição provocada pelos incêndios, au das plenas manifestações dos riscos hidrogeomorfológicos que eles desencadearam, pretende valorizar a importância das reabilitações que foram ou deveriam ter sido levadas a efeito nas áreas afectadas .

Palavras chave: análise de risco, incêndios florestais, erosão, reabilitação.

\section{RÉSUMÉ}

Les montagnes du centre du Portugal ont été fréquerment frappés par des violents incendies de forêt, $C^{\prime}$ est pourquoi nous devons nous référer à l'Açor, parce qu' elle présente aujourd' hui l'un des plus haut taux de récurrence des feux de forêt au Portugal.

Parmi les nonbreux incendies qui ont détnuit forêts et maisons dans la partie nord se distinguent ceux que, par la gravité et la taille de la zone affectée, sont enregistrés entre 13 et 20 Septembre 1987 et entre 19 et 24 Juillet 2005, chaqu'un d'eux avec une surface brûlée de plus de 10000 hectares.

Par coïncidence, une partie de cette surface est comme aux deux incendies et, en autre, également dans les deux cas, des épisodes de pluie intense sont produits au caurs des amées qui suivent immédiatement l' incendie deforêt.

Après la pleine manifestation du risque d' incendie, des événements pluvieux ont provoqué aussi la pleine manifestation du risque d' érosion, et certaines d' autres conséquences graves en termes de destruction de biens et même perte de vies humaines.

Ce travail taut en identifiant certains des domaines qui ont été tadhées, plus de faire face aux destructions causées par les incendies, ou la pleine manifestation des risques hydrogéonorphologiques il prétend montrer l' importance de la réhabilitation qui a été au devrait être réal isée dans des zones tauchées.

Mbts-clé: analyse des risques, incendies de forêt, érosion, réhabilitation. 


\section{ABSTRACT}

The mountains of central Portugal have been frequently stricken by violent forest fires, which is why we have to refer to the Açor, because it presents one of the highest rates of rearrence of forest fires in Portugel.

Among the many fires that have destroyed forest and houses, in the northem part of Portugal, stands at, by the seriousness and the size of the affected area are, the fires recorded between 13 and 20 september 1987 and between 19 and 24 Jily 2005, both with area bumt over 10000 hectares.

coincidentally, a part of the bumed area common to both and, moreover, also in both cases, there were rainy intensive episooles in the years imediately following the forest fires.

Thus, after the full manifestation of fire hazard, full events ocarr leading witherosion hazard, and some other seriaus consequences in terms of destruction of property and even loss of human life.

This work, while identifying some of the areas that were affected, more than cope with the destruction caused by fires, or the full manifestation of the hydrogeomonphologic hazards they caused, is to qptimize the importance of rehabilitation that have been or should have been carried at in areas affected.

Keywords: risk analysis, forest fires, erosion, rehabilitation.

\section{Introdução}

A Região Centro e, em particular, as serras da Cordilheira Central (Lousã, Açor e Estrela, a Norte do rio Zêzere, Alvelos, Cabeço Rainho e Grordunha, a Sul desse rio, paramencionar apenas as principais (fig. 1) têm sidb fustigadas por violentos incêndios florestais, aos que, normalmente, se seguemprocessos erosivos, mais ou menos violentos, em função quer das ) características geomorfológicas da área afectada, quer da duração e intensidade da precipitação.

Se, parte destas situaçães erosivas, sobretudo algumas das associadas a infra-estnuturas florestais, poderiam ter sidb prevenidas, muitas atras, momente

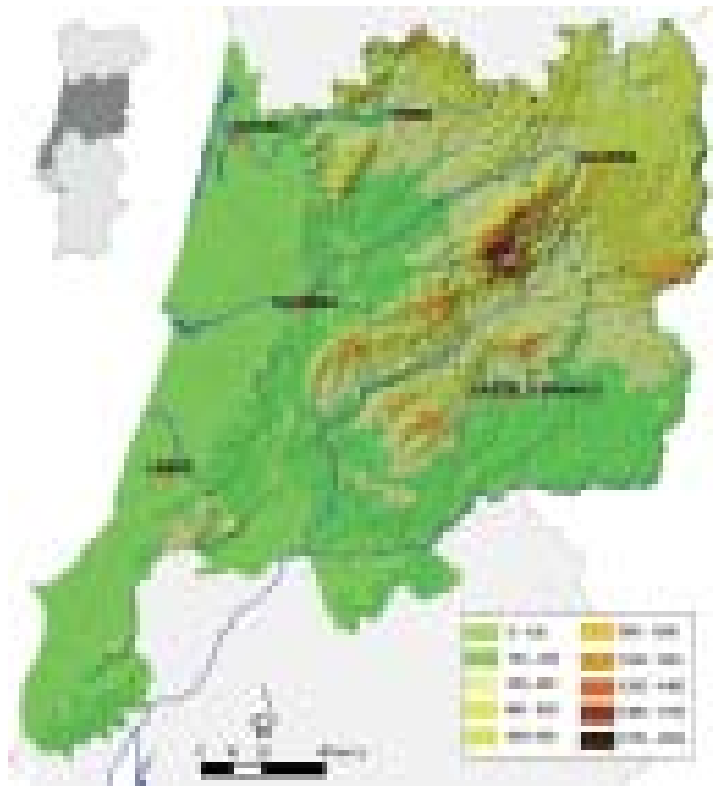

Fig. 1 - Frquadramento geográfico da cordi lheira central portuguesa aquelas que acompanharam as precipitações mais violentas, dificilmente poderiam ter sidb evitadas.

No entanto, todas elas afectaram áreas, mais ou menos vastas, que deveriam ter sido reabilitadas. É dovio que o custo que tal implicaria para as devolver à situação inicial é incomportável, numa análise de austobenefício, mas tal não implica que não pudessem ser efectuadas algumas intervenç̃es simplificadas, como abjectivo de minorar as riscos, designadamente, as ambientais, que decorrem dessa não intervenção, como vamos procurar demonstrar, valorizando, sobretudo, as situações mais recentes, porque, dadb o interesse turístico das áreas envolvidas, forammerecedbras de alguma reabilitação.

A metodologia que seguimos baseou-se, essencialmente, no levantamento das situações de que fomos tomando conhecimento, quer por contactos directos, quer através da commicação social, e na posterior recolha de elementos com elas relacionadbs, efectuada através da consulta de diversos dbamentos de base-cartografia, séries estatísticas, relatórios, projectos, ...-bem como, sobretudo, no reconhecimento e trabalho de campo, não só para recolha directa de elementos físicos, mas também para, junto dos residentes que testemunharam e viveramessas situaçães, doter os seus relatos pesscais dos factos.

A informação que, entretanto, foi sendb reunida, deu origem a diversos artigos que, com mais ou menos pormenor, relataram algumas dessas situações, pelo que não cabe agora aqui desenvolvê-las de novo. Apenas se referem, para demonstrar que o fenómeno é bem mais frequente do que se imagina, e, em determinadas circunstâncias, pode ter consequências bem nefastas, as quais, por vezes, se manifestam 
bastante tempo depois da ocorrência e extinção dos incêndios florestais, mas que só a eles são devidas. Com efeito, se a vegetação não fosse destnuída pelas chamas, as águas selvagens não teriam tanto poder erosivo e, por conseguinte, os seus efeitos nunca assumiriamtal significadb.

Deste modo, depois de uma breve referência a diversas situações investigadas na Região Centro, em materiais litológicas diferentes - xisto, granito e calcário -, centramos a nossa atenção nalguns dos locais onde se procedeu a reabilitação de áreas afectadas, com particular destaque para as imediações do Piódão.

\section{Erosão após incêndios florestais, um fenómeno recente em Portugal?}

Os incêndios florestais, enquanto combustões descontroladas (no tempo e no espaço) , involuntária ou deliberadamente provocados pelo ser humano, bem como os fogos, entendidos como combustões controladas, contribuem, desde há muito, para o aumento dos efeitos causados pelos processos erosivos, sdoretudb os de origem hídrica, nas vententes por eles afectadas.

O primeiro registo que encontrámos sobre este assunto refere-se a ma Carta Régia, escritaporD. Afonso V, em Tentúgal, com data 22 de Setembro de 1464. O documento pertence à colecção de pergaminhos do Arquivo Histórico Municipal de Coimbra, está registado cam o n. 84 (fot. 1) e dá-nos conta deste problema antigo, com mais de quinhentos anos, quando o monarca ordenou que: " [...] a requerimento da cidade e para evitar a continuação dos grandes danos provocados pelo assoreamento do Mondego, se proibiu que de Coimbra a Seia se pusessem fogas até uma légua das margens do Mondego [...] " .

De facto, os problemas de assoreamento do Baixo Mondego, bem mais antigos e com uma longa história, envolvendb várias tentativas de resolução, também são bem conhecidas (A. Ferrnandes Maritns, 1940, p. 87 e 176-206). Foram várias as intervençães no sentido de reabi 7 itar aquele espaço, com grande aptidão agrícola.

As mais significativas, porque de maior envergadura, são o projecto hidráulico do P. e Estevão Cabral, que se iniciou em 1791, com a abertura de um novo álveo (quase recto) para o rio Mondego, desde Coimbra a jusante de Montemor-o-Velho (DG, 1822, p. 690-2) , e o "plano geral do aproveitamento hidráulico da bacia do rio Mbndego", de 1962, que preconizava não só a regularização das cheias, nas albufeiras a criar a montante, mas também o aproveitamento conjunto dos campos do Mondego e de Cantanhede ao Vouga. Posteriormente, foi

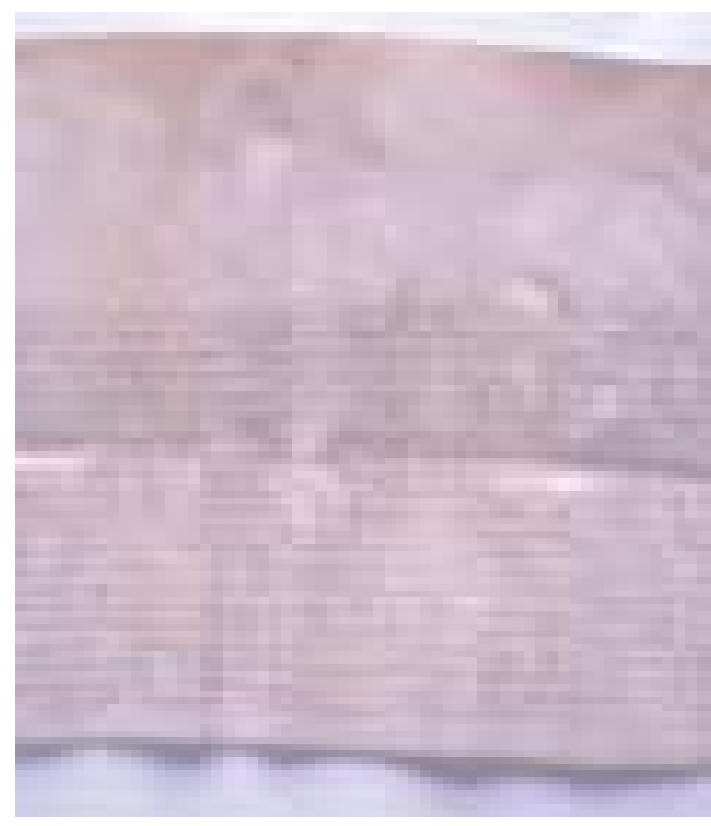

Fot. 1 - Extracto da Carta Régia de D. Afonso V, de 22 de Setembro de 1464.

adaptado e deu origem ao "Aproveitamento Hidráulico do Vale do Mondego" (DGRN, 1988), em que a opção de rega dos campos do Baixo Vouga foi abandonada, por não ser viável.

Não obstante, a realização da primeira fase deste vultuoso empreendimento, o problema das inundaçães dos campos do Baixo Mondego não ficou completamente resolvido, como o comprovaram as cheias ocorridas no Inverno de 2000/01 (P. CtrFA, 2002 e P. PAIRIHA, 2004).

\section{Fenómeno erosivos associados a incêndios florestais, anteriores a 2005}

Se referimos algumas das situações estudadas anteriormente àquela que deu origem a este artigo é, apenas, porque parte da área que estudámos há cerca de 20 anos voltou, de novo, a ser palco de um grande incêndio florestal e, também, de processos erosivos semelhantes, como veremos adiante.

Então, como agora, os efeitos erosivos foram particularmente visíveis emdiversas infra-estnuturas, quer estradas e caminhos florestais, que se desenvolvem ao longo das vertentes, quer empontes, diques, campos agrícolas e praias fluviais, existentes ao longo das principais linhas de água. Esta situação repetiu-se com alguma frequência e, porque ocorre em diferentes materiais litológicas, entendemos ser de apresentar sumariamente, através de referências bibliográficas a alguns dos exemplos mais paradigmáticos, por terem registado processos erosivos violentos, após incêndios florestais. 
Serra do Açor (Arganil) , 1988

A primeira manifestação do risco de erosão após incêndios florestais que acompanhámos diz respeito à que se seguiu ao incêndio florestal que, de 13 a 20 de Setembro de 1987, afectou uma parte substancial da serra do Açor, nos concel has de Arganil, Pampilhasa da Serra e Oliveira do Hospital, tendo percorrido, durante 7 dias consecutivos, cerca de 10900 ha, e, terá sido o maior registado até então e o segundo a ultrapassar a barreira dos 10000 hectares. 0 primeiro incêndio florestal comuma área superior a 10 000, terá sidb o de Vila de Rei - Ferreira do Zêzere que, no ano anterior, 1986, terá consumido cerca de 10800 hectares de floresta.

Numa primeira fase, acompanhámos os processos erosivos desencadeados na sequência de precipitações registadas em condições meteorológicas consideradas normais, durante o autono e o Invemo imediatos ao incêndio (L. Laknşo, 1988a) e, depois, também no Verão seguinte, desta vez em resultado de condições meteorológicas mais severas, associadas ao temporal que, em 23 de Junho de 1988, se abateu sobre uma parte considerável da área afectada pelo incêndio, sobretudb na bacia hidrográfica da ribeira de Pomares (L. Iarenço, 19886) .

\section{Serra das Caveiras (Góis), 1991}

Do mesmo modo, também em morfologia de xisto, na Quinta de Belide, situada na serra das Caveiras, concelho de Góis, foram destruídos alguns campas agrícolas, no Invemo de 1991, (L. Latwnş, 1995; J. FialHo e L. Lourenço, 2007)) bem como, também, a estrada de acesso à Quinta, que ficou completamente intransitável (fot. 2) e ajja reabi litação tardaralguns anos a concretizar-se.

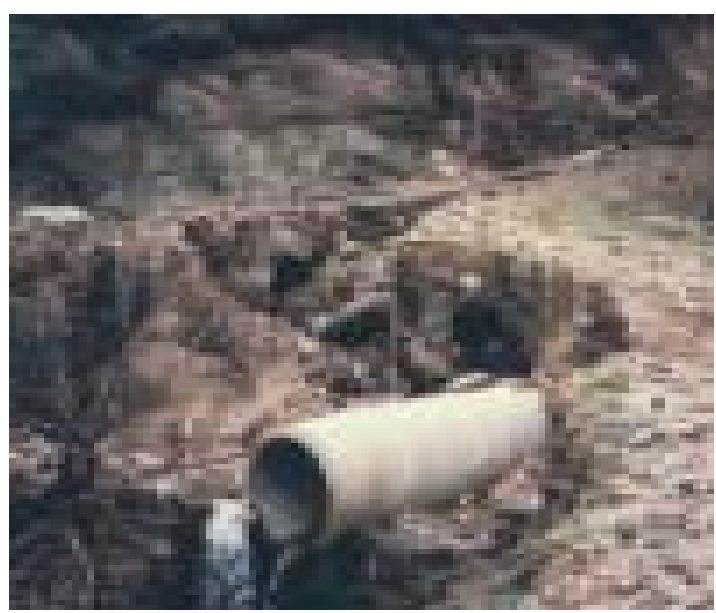

Fot. 2 - Pormenores de aspectos erosivos produzidos na estrada de acesso à Quinta de Belide (Góis) , durante o Outono e o Inverno de 1990/91.
Serra da Estrela (Manteigas) , 1993

Dois anos depois, na madrugada do dia 16 de autubro de 1993, foi a vez do risco de erosão após incêndio florestal se voltar a manifestar, agora na serra da Estrela e num contexto morfológico diferente dos anteriores, ou seja, sobre material granítico, tendo-se iniciado nas cabeceiras da ribeira da Albargueira (Manteigas) e desenvolvido ao longo do leito da ribeira, uma verdadeira torrente, pelo que a área mais afectada situou-se na sua parte vestibular, correspondente ao cone de dejecção, ande se localiza o Hotel das Termas (do Inatel) nas Caldas de Manteigas, imediatamente antes da confluência com o rio Zêzere. Além deste equipamento hoteleiro, as estradas que atravessam a ribeira, foram as infra-estnuturas mais afectadas (L. LaRenço e A. C. DiREITIO, 1994).

\section{Serra da Senhora do Mbnte (Leiria) , 2003}

Esta situação aconteceu dez anos depois da anteriormente descrita, tendb ocorridb nas imediações das Cortes (Leiria) , na sequência do incêndio florestal que, em 2 de Agasto de 2003, devastou essa área (L. LOUREnço e N. CunHa Lopes, 2004) .

Os efeitos erosivos mais evidentes aconteceram na serra da Senhora do Monte, mais precisamente da Cascalheira até ao Vale das Fontes (a Sul) e do Vale Fernando ao Vale da Abadia (a Nascente) e, como foi profusamente relatado pelo mensário regional, Jormal das Cortes (C. FERNRnEs, 2003; R. SÁ PeSSOA e C. A. SHIA, 2004), a reabilitação desta vasta área não aconteceu.

Com efeito, normalmente, a prevenção é umpilar pobre do sistema de protecção civil, e não se prevenindo as situaçães, não se evita ou, pelo menos, minimiza a manifestação destes riscos. Por conseguinte, habitualmente, a solução de recurso éa do socorro e, porque momentânea, não resolve os problemas de fundo, apenas tenta remediar situações que mereciam outro tipo de tratamento.

Nb dizer dos jomalistas, "primeiro foi o fogo e as cinzas. Apás o fogo, aconteceu a enxurrada. O monte foi fustigado pela fúria das águas. Agora, são as águas indomáveis. É a erosão imparável, sem que nenhuma medida se tome" .

Com efeito, o terceiro pilar do sistema, a reabilitação, será dos três, certamente, aquele que menos atenção tem merecido, razão que nos levou a destacá-lo neste texto, dando conta dos poucos exemplos de infra-estnuturas que foram recuperadas em áreas ardidas e, pasteriormente, afectadas por processsas erosivos pás-incêndios. 


\section{Reabilitações dignas de nota, no século passado}

Ainda que, por vezes, os incêndios florestais pareçam ter emergido com a revolução do 25 de Abril de 1974, devido ao seu grande incremento a partir de então, fruto das profundas transformações porque, desde então, passou a sociedade portuguesa, a realidade é que eles são muito antigos, como já referimos. Por vezes, até tiveram consequências catastróficas, como foi o caso, por exemplo, da povoação do Vale do Rio (Figueiró das Vinhos) que, no dia 28 de Agosto de 1961, foi completamente destruída por um violento incêndio. Vejamos, pois, duas situaçães de reabi litação, uma delas anterior e, a autra, posterior a essa data.

\section{Recuperação de povoações. Dois exemplos}

Três anos depois da situação acabada de mencionar, em 24 de Outubro de 1964, foram inauguradas as doras de reconstrução da aldeia (fot. 3-A) , que, entretanto, parece ter ficadb completamente parada no tempo e votada ao abandono.

O regresso a esta aldeia, passados cerca de vinte anos, deixul-nos estarrecidbs, tendb-se apoderadb de nós uma sensação muito estranha, confrangedora, por verificarmos o estadb a que chegar e que o seu aspecto
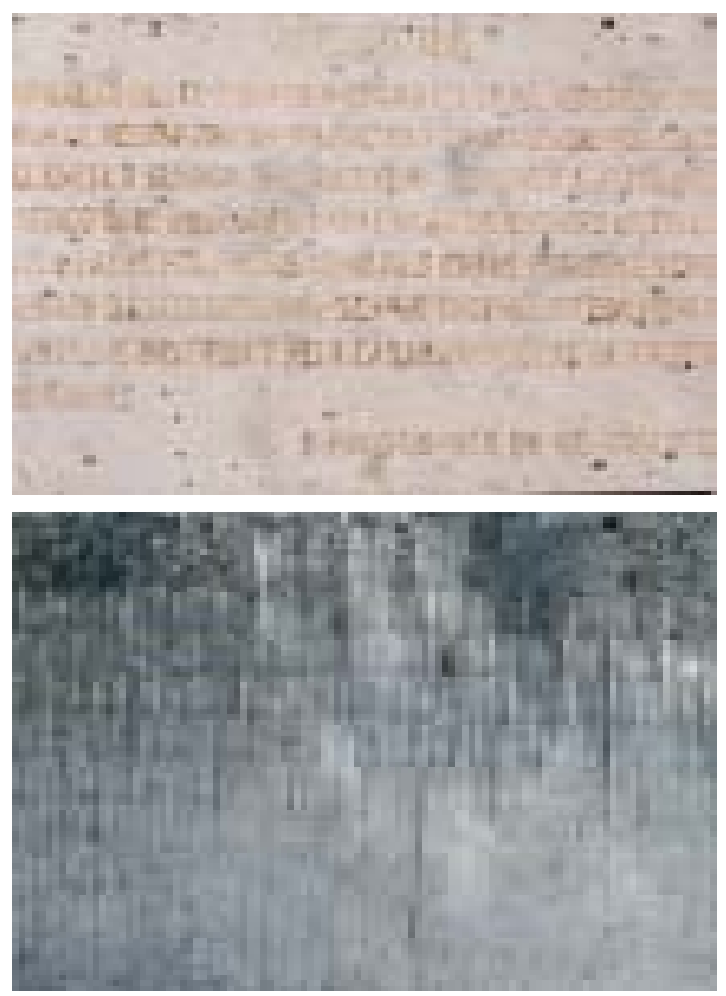

Fot. 3 - Iápide que testemunha a reabilitação da aldeia de Vale do Rio, depois de ter sido destruída por um incêndio florestal, de 28 de Agosto de 1961: A - Em cima, fotografia tomada em finais da passada década de oitenta. B - Em baixo, aspecto actual, completamente ilegível (7 de Setembro de 2009) . geral nos transmite, estandb bempatente quer na placa comemorativa (fot. 3-B) , quer na antiga escola primária, emajo interior crescemeucaliptos (fot. 4) .

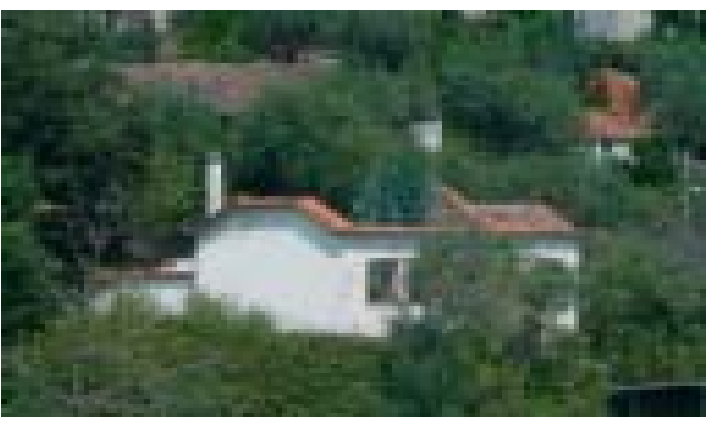

Fot. 4 - Pormenor da antiga escola primária do Vale do Rio, um exemplo do desinteresse e da falta de empenho na procura de soluçães para resolução das problemas de despovoamento e autros que afectam o interior do país.

Ariosamente, vinte e dois anos mais tarde, em 1983, no vizinho concelho de Pedrógão Grande, foi a vez da aldeia do Rabigordo ser destruída por autro incêndio florestal. A reabi l itação também ocorreu, mas levou demasiados anos, pois obedeceu a critérios bem diferentes. Nesta reauperação, o que restau das casas foi inteiramente demolidb e procedeuse à construção de novos edifícios, cujas doras, passados oito anos estavam completamente paradas (L. LaRenç, 1992), revelando até um certo estado de degradação e abandono (fot. 5) .

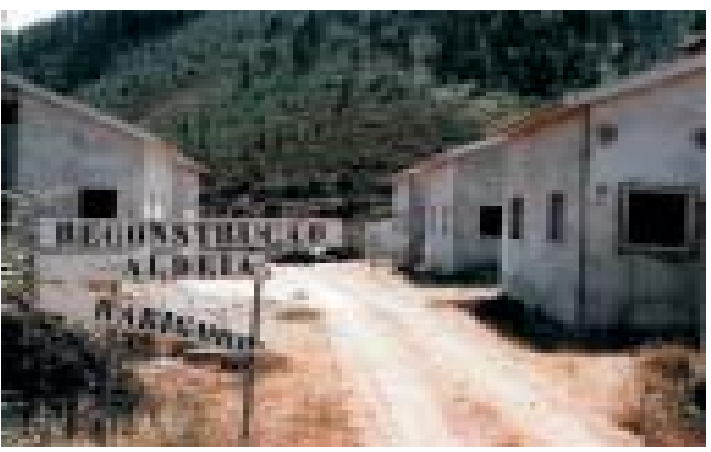

Fot. 5 - Aspecto de Rabigordo, em 1991, durante a fase de intermupção das doras de reabilitação da aldeia, oito anos após o incêndio que, em 1983, a tinha devastado.

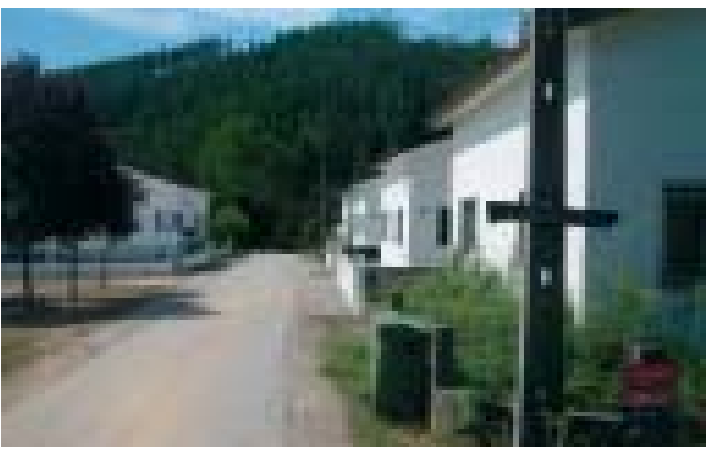

Fot. 6 - Aspecto de Rabigordb, na actualidade (Setenbro de 2009) . 
A sua conclusão tardou, pois esteve dependente da elaboração de candidatura a novo Quadro Commitário de Apoio e à respectiva aprovação, processo que se arrastou por demasiado tempo, o que levou os anteriores residentes a qptarem por novos locais. Hbje, a aldeia, que foi totalmente reaperada (fot. 5) , apesar do seul aspecto de nova, encontra-se praticamente abandonada, servindo apenas de residência secundária, segunda habitação, em tempos de férias. Das seis casas que foram construídas de novo, duas delas, uma à entrada e outra à saída da aldeia, parecemnunca ter sidb habitadas, não possuem estores, os logradaros estão cheios de silvas e, pelo menos, uma delas encontra-se à venda (fot. 6) .

\section{Recuperação de attras infra-estnuturas}

Apesar de, com o passar dos anos, aparentemente, as famílias estarem cada vez mais seguras e protegidas, o que se tem verificado é que, apesar disso, quando tem havido necessidade de reabilitar habitações destruídas pelos incêndios, a resposta, normalmente, tarda em chegar.

Assim, não admira que, quando se trata de autras infra-estruturas, designadamente, das existentes na vasta área afectada pelos fenómenos erosivos associadbs a incêndios florestais anteriores a 2005, referidos no número anterior, apenas pontualmente se verificau alguma reabilitação de infra-estnuturas ligadas à circulação (pontes e estradas) a ao lazer, como foi o caso da praia fluvial de Avô (fot. 7e 8), que voltaria a ser completamente destruída em 2006.

Ainda hoje, passados mais de vinte anos depois da catástrofe, ainda é possivel doservar muitos locais em que a degradação continua, pois não sofrerem qualquer intervenção, no sentido de os reabilitar. É suficiente percorrer alguns quilómetros do vale da ribeira de Ponares, a montante de Avô, para, em locais facilmente acessíveis, ainda se poderem observar alguns dos efeitos erosivos provocados nos campos marginais da ribeira, pela enxurrada de 1988, por nunca terem sidb alvo de reabilitação.

Na verdade, os efeitos erosivos mais violentos registam-se, em regra, nos fundos de vale das maiores ribeiras, onde não se procede a qualquer tipo de reabil itação, o que também se aplica à generali idade das áreas ardidas que, assim, abandonadas à regeneração natural e aos grandes incêndios, de uma floresta pujante cederam lugar ao mato.

E, com os anteriores acontecimentos de 1988 já tão longe na memória, tudo parecia estar resolvidbe a funcionar na plenitude, mas, eis senão quando, a serra do Açor voltou a ser palco de um novo grande incêndioflorestal.

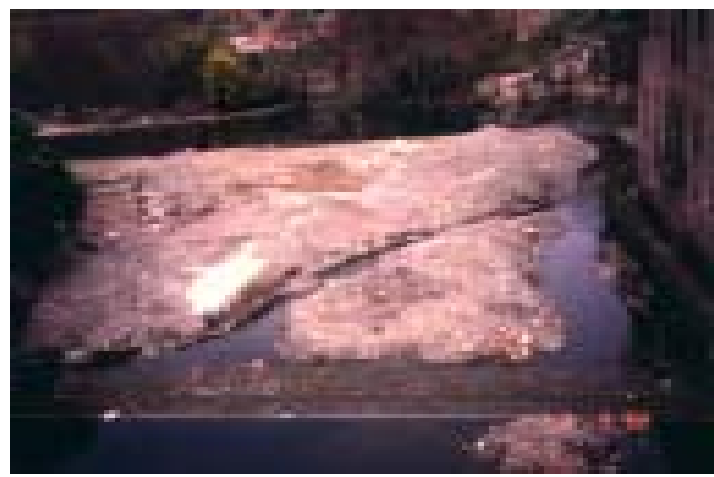

Fot. 7-A - Aspecto de pormenor da praia fluvial de Avô, em Julho de 1988, após a enxurrada de 23 de Junho desse ano.

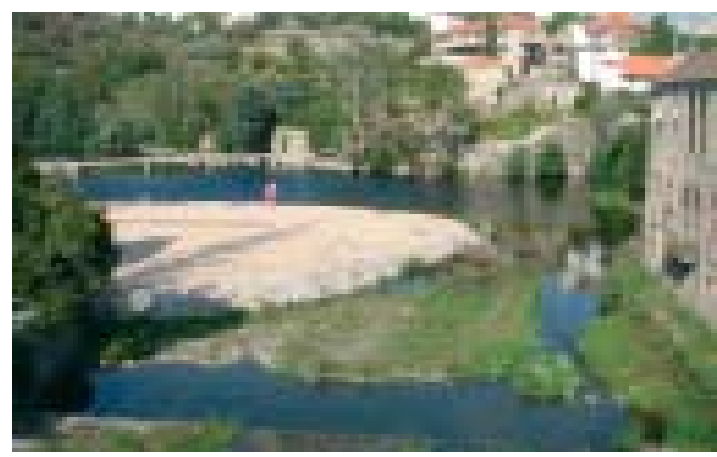

Fot. 7-B - Idem, em Setembro de 2009, após as últimas dbras de recuperação, realizadas na sequência das cheias de 2006.

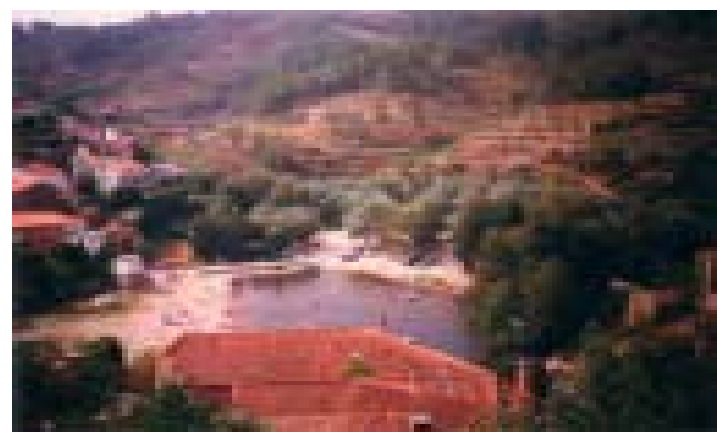

Fot. 8-A - Vista da praia fluvial de Avô, anos depois das primeiras doras de recuperação.

Fonte: http://1.bp.blogspot.com/ c5LohovrYYJc/SRVV3uSboN6I/ AAAAAAAAAJw/Czdw4CcgCSg/s1600-h/Scan10001. BMP

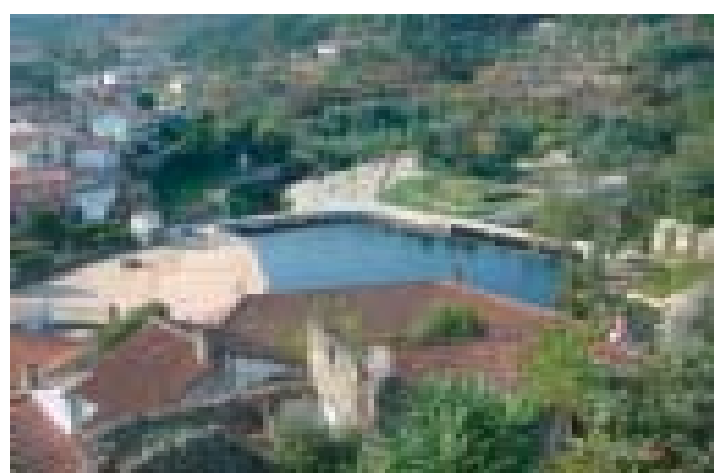

Fot. 8-B - Vista geral da praia fluvial, em Setembro de 2009, após as últimas doras de reabilitação. 
A repetição de crises de grande incêndio florestal e de erosão violenta pós-incêndio, na Serra do Açor, nos anos de 2005 e de 2006

Em 2005, um incêndio florestal de grandes proporções desenvolveu-se numa área que, emparte, se sobrepôs à que tinha sido anteriormente queimada no ano de 1987. De igual modo, também no ano seguinte, em 2006, voltau a manifestar-se a actuação violenta dos processos erosivos, sobretudo de natureza hídrica, semelhantes aos verificados em 1988, razão que nos leva a fazer-lhes uma breve referência, pois assim será mais fácil compreender a reabilitação efectuada posteriormente e que é o principal dojectivo deste estudb.

contudo, esta só aconteceu pelo facto de uma parte substancial da área afectada, tanto nas imediaçães do Piódão, como na Vide ou em Avô, ser de grande interesse turístico, o que levou ao desencadear de importantes processos de reabil itação que vale a pena mencionar.

\section{5 - O incêndio de 19 a 24 de Jüho}

Com uma área ardida superior a 16.000 ha, este incêndio afectou, ao lango de uma semana, terras de seis municípios: Seia, Oliveira do Hospital, Arganil, Pampi lhosa da Serra, Covi lhã e Fundão. Grande parte da área percorrida por este incêndio apresenta uma das maiores taxas de reincidência da área ardida em Portugal (A. Nave e L. Iaknķ̧, 2007). Além disso, por coincidência, em parte da área afectada pelo incêndio de 1987 (fig. 2) , , correspondente às bacias hidrográficas das ribeiras de Pamares e do Piódão, voltaram agora, em 2006 (fig. 3) , a manifestar-se intensamente os riscos de erosão hídrica após

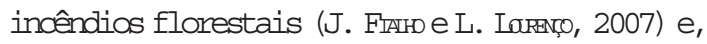
também, de inundação das áreas ribeirinhas (N. PAw HIFA e L. Larenço, 2007), como mencionaremos, commais detalhe, a continuação.

2006 - Processos erosivos subsequentes aos incênotios

Tendo em consideração que, quando o solo está desprovido de vegetação, por ter sido queimada por incêndios do Verão anterior, a água da chuva embate directamente no solo, contribuindb o seu impacte para a desagregação deste, através do conhecido efeito de "salpico".

como, além disso, nas bacias hidrográficas antes referidas, as declives são, normalmente, bastante elevados, a escorrência ganha grande poder erosivo, que aumenta com a concentração das águas, sobretudo quando são provenientes de aguaceiros violentos, associadbs quer a precipitações intensas quer a precipitações prolongadas. Ora, na área em estudb, verificaram-se precisamente estas duas situações.

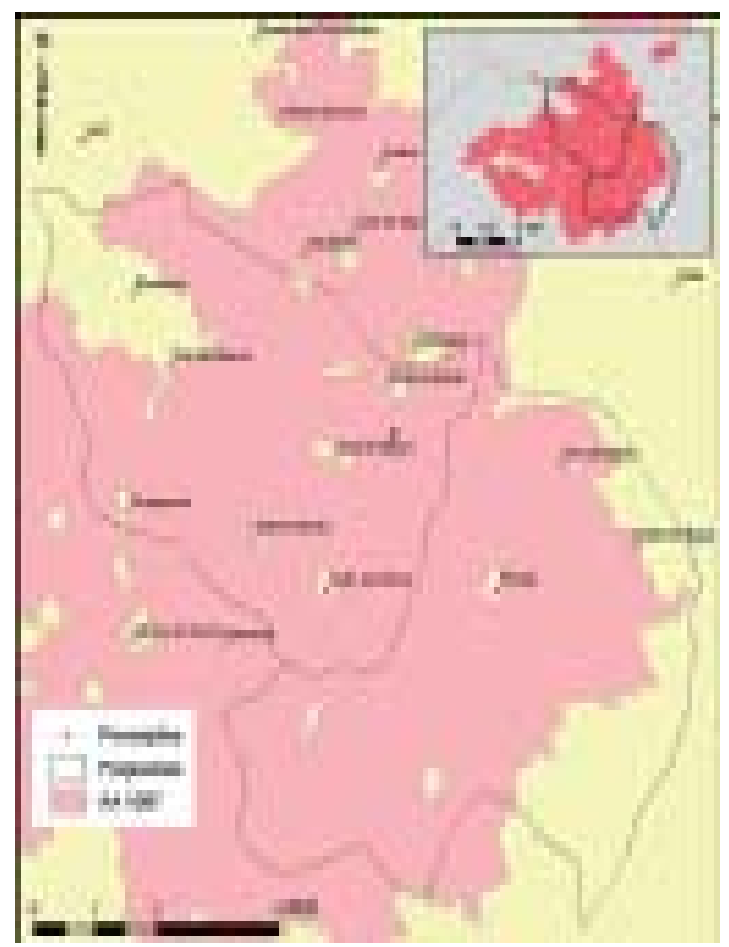

Fig. 2 - Pormenor da área queimada, nas freguesias de Pomares e Piódão, pelo incêndio florestal de 1987 (em cartela) . Fonte: N. ParRERA e L. Larenço (2007, p. 128) .

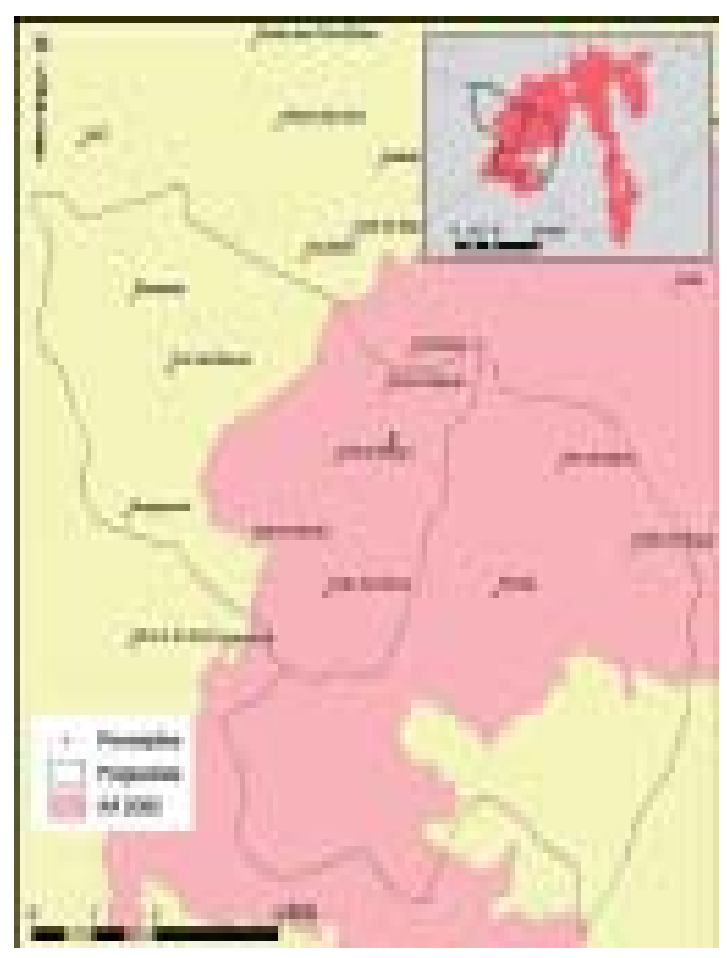

Fig. 3 - Detalhe da área queimada, nas freguesias de Pomares e Pióoão, durante o incêndio florestal de 2005 (em cartela) . Fonte: N. Perkira e L. Latanço (2007, p. 129). 


\section{6 - Precipitações intensas}

Primeiro, foram as precipitações intensas, que ocorreram, respectivamente, a 16 de Junho e a 14 de Jilho de 2006 (figs. 4 e 5) , em resultado de grande instabilidade atmosférica, que conjugou mecanismos convectivos do ar com ascensões orográficas violentas, originando precipitações importantes e muito concentradas no tempo e no espaço.

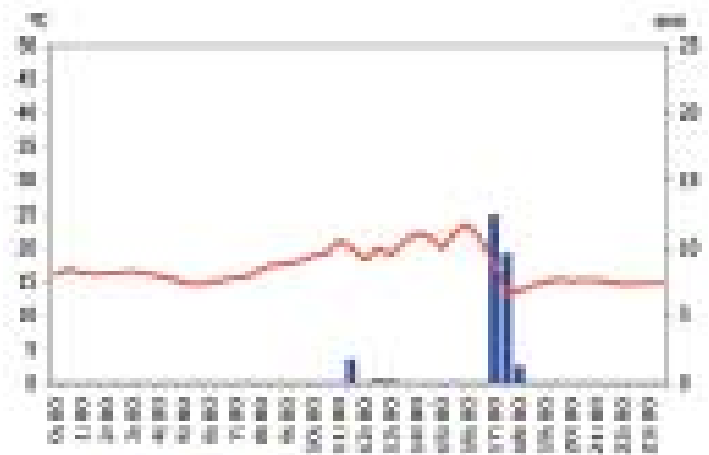

Fig. 4 - Diagrama ombrotérmico semi-horário do Piódão, referente ao dia 16 de Junho de 2006.

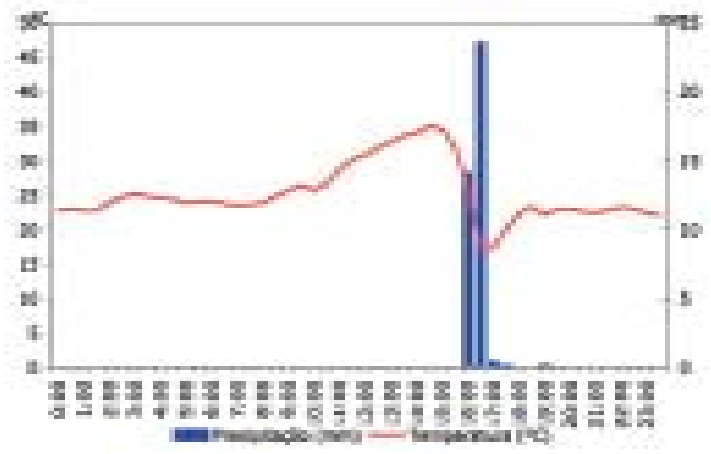

Fig. 5 - Gráfico termopluviamétrico semi-horário do Piódão, relativo ao dia 14 de Julho de 2006.

Além das muitas e profundas marcas que deixaram na paisagem, as consequências destas precipitaçães são bem conhecidas (L. Lakņ̣̃, 2006; J. FIAHL e L. Lafanco, 2007), sobretudo porque o segundo episódio pluvioso acabou por provocar uma vítima mortal. Tal facto obrigou ao desencadear duma operação de resgate, levada a efeito pela protecção civil, o que associado ao desaparecimento do cadáver durante vários dias, deu origem a ampla cobertura mediática .

Assim, de entre as infra-estnuturas danificadas, foram as associadas à circulação rodoviária, sobretudb aquedutos, e, também, as ligadas ao lazer, tais como piscinas e praias fluviais, que, de novo, voltaram a ser as mais afectadas e danificadas.

Enquanto as primeiras sofreram maiores danos nas imediações do Piódão (L. Laknkço, 2006; J. FiatHo e L. Larenço, 2007), as segundas tiveram uma maior dispersão, designadamente, na ribeira de Pomares, tendb afectadb as piscinas fluviais do Soito da Ruiva, Sobral Magro e Pomares, bem como as do Piódão e da Foz de Égua, na ribeira do Pióoão, e a da Vide, no rio Alvoco. As praias fluviais também foram danificadas, especcialmente as de Alvoco de Varrzeas, no rio Alvoco (fot. 9) , e, novamente a de Avô, no rio Alva (N. Pereira e L. Lourenço, 2007; J. FialHo e L. LOURENÇO, 2007).

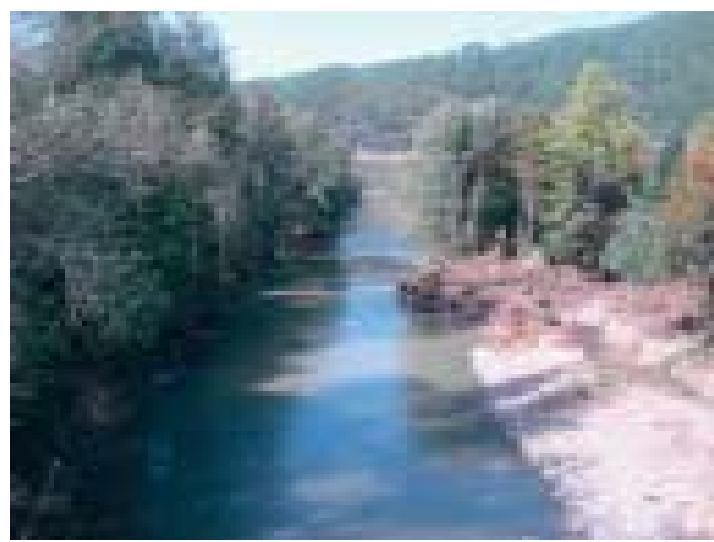

Fot. 9-A - Aspecto da praia fluvial de Alvoco, em parte fossilizada com material abandonado, obtido no dia 28 de Dezembro de 2006.

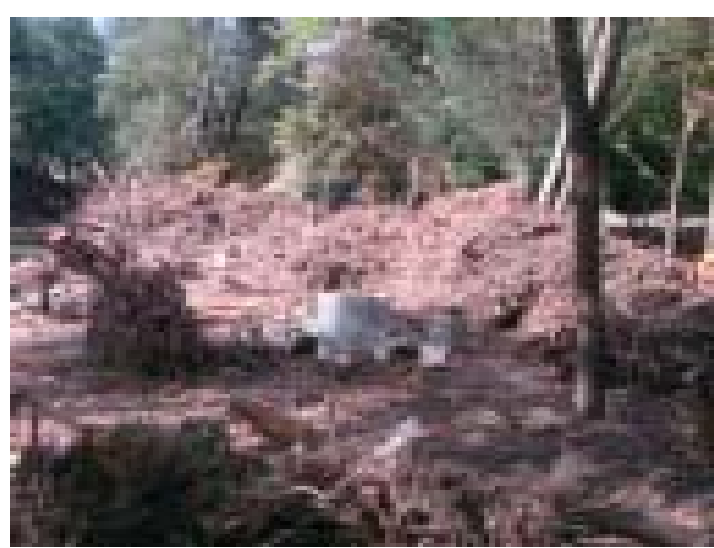

Fot. 9-B - Vista do parque de merendas da praia fluvial de Alvoco, completamente soterrado com material deixado pelo Alvoco, tirada em 28 de Dezembro de 2006.

\section{6 - Precipitações prolangadas}

O início do Outono foi marcado por uma sequência pluviosa relativamente prolongada, associada à passagem de diversos sistemas frontais, alguns deles muito activos e que descarregaram precipitaçães importantes, como sucedeu no Pióoão, a 21 e 23 de Setembro, em que cada um desses dias registau mais de 30 mm de precipitação, e, sobretudb, no mês seguinte, em que nos dias 22 e 25 de autubro 
caíram respectivamente, 84,84 e 73,63 mm de chuva (figs. 6e7) .

Ora, se as anteriores precipitações intensas actuaram, sobretudo, em termos de desagregação e escavamento do solo, tendo, depois, transportado muitos materiais, parte dos quais ficou abandonada ao longo dos cursos de água, o resultado destas precipitações prolongadas notou-se, principalmente, na remoção desses materiais e no respectivo transporte mais para jusante, comprometendo algumas das acções de reabi litação que, entretanto, foram levadas a efeito, nomeadamente, na praia fluvial de Avô, que voltou a ser uma das mais afectadas.

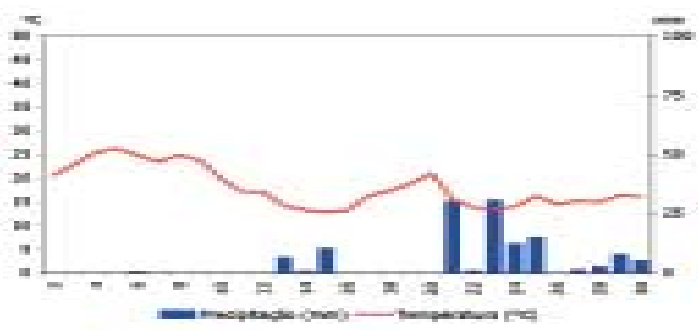

Fig. 6 - Distribuição dos valores diários de precipitação e temperatura média, durante o mês de Setembro de 2006, na estação meteorológica do Piódão.

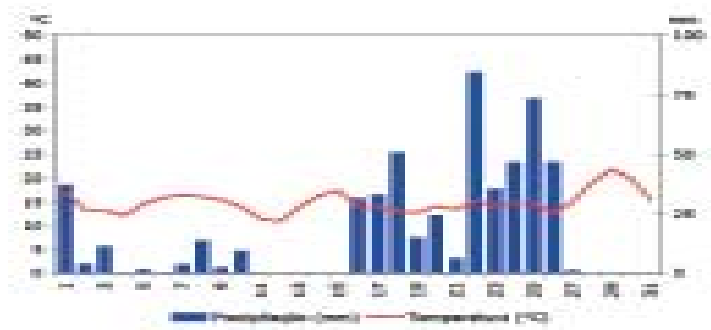

Fig. 7 - Diagrama termopluviamétrico da estação meteorológica do Piódão, referente ao mês de outubro de 2006.

\section{Reabilitação da área percorrida pelo incêndio florestal de 2005}

Depois da visualização de imagens chocantes que, normalmente, acompanham as transmissões televisivas dos incêndios mais mediáticos, évulgar a disponibi l ização de recursos, por parte de diversas instituições, para replantar a área ardida, se bem que, muitas vezes, por falta de enquadramento adequado, essa disponibilidade acaba por ficar pelas "boas intenções" e de pouco mais serve do que para fazer "nobre e honrosa" publicidade a essas mesmas instituições.

Com efeito, ao consultar o portal da Caixa Geral de Depósitos facilmente se encontra, no Fundo Caixa
Fã, uma referência ao projecto que pretendia "conseguir a total reflorestação do Piódão" e, para tal, seriam necessários, apenas, 23.625,00€. o projecto consistia no seguinte :

\section{"ACÇÕES DE FLORESTAÇÃO}

Piódão, Arganil, 7 de Novembro de 2008

A Caixa Geral de Depósitos, em parceria com a Associação Nacional de Empresas Florestais, Agrícolas e do Ambiente (ANEFHA) e a Associação de Compartes da Freguesia do Piódão, levou a cabo a reflorestação da área ardida do Piódão. Participaram nesta acção [...] . ( (Neste contexto, a reflorestação da área ardica - 74\% da freguesia - consubstanciou uma intenção firme e enérgica, por parte de diferentes entidades, de fazer face às graves consequências da catástrofe que atingiu a freguesia do Piodão. ( (Este projecto constitui, assim, um importante contributo para a promoção da sustentabilidade, nas suas diferentes componentes, social, económica e ambiental, designadamente através da defesa e divulgação dos valores naturais e culturais. Para a concretização deste projecto foram necessárias 15.000 plantas, com a seguinte distribuição por espécie: Medronheiros: 5.000, Azinheiras 2.100, Cerejeiras 2.200, Carvalhos 2.200, cedros 2.000 e Sobreiros 1.500.

A escolha das espécies a plantar visou, por um ladb, a reposição das espécies autóctones existentes antes do incêndio e, por autro, a substituição de uma mancha de pinheiro bravo por medronheiros e azinheiras, contribuindo, assim, para o aumento da biodiversidade e para a promoção das espécies autóctones da região."

No entanto, quando percorremos a área envolvente do Piódão, não encontramos as mencionadas plantas, ao contrário do que a notícia deixa antever. É que, para "reflorestar" não basta comprar e oferecer as 15000 árvores. É necessário plantá-las e, depois, cuidá-las, para o que também são necessários fundos! Em alternativa, essa plantação e a posterior manutenção podem organizar-se com recurso a cidadãos voluntários, todavia, para tal, é necessário alterar mentalidades, o que só se resolve com educação florestal que tarda a instalar-se neste país que também poderia ser de floresta. De facto, oproblema da floresta portuguesa não se resolve com a plantação "simbólica" de, apenas, meia dúzia de árvores!

Deste modo, salvo uma ou outra honrosa excepção, a generalidade da área queimada ficou entregue a si mesma e o que agora se observa é a regeneração do mato, onde, aquém e além, se destacam, isoladas ou em pequenos bosquetes, algumas folhosas que, entretanto, rebentaram das suas toiças. É este, infel imente e cada vez mais, o triste panorama dos espaços portugueses com aptidãoflorestal.

\{http://www.cod.pt/Institucional/Responsabilidade-Social/Anbiente/Floresta-Caixa/Accoes-Florestacao/Pages/Piodao.aspx\} 


\section{Reabilitações recentes em áreas afectadas pela manifestação violenta de processos erosivos desencadeados na sequência do incêndio de 2005, na serra do Açor}

Volvidos mais de quatro anos sobre o último grande incêndio florestal da serra do Açor, as doras de reabi litação das infra-estnuturas viárias da área mais afectada foram finalmente inauguradas, em 2 de Setenbro de 2009, sem que, no entanto, estivessem ainda terminadas.

Contudo, algumas autras, designadamente, as de recuperação de piscinas fluviais, foram concluídas antes, por vezes com grande envolvimento e muito trabalho voluntário de populares, dinamizado pelas respectivas Comissões de Mel horamentos. Nb entanto, a reabil itação da piscina do Pióoão, nessa data ainda não tinha sidb iniciada.

Digno de nota, em termos de recuperação e de valorização, é o inovador paradigma de mudança, instituído no Piódão pela Associação de compartes de Baldios em parceria com a Junta de Freguesia que, em conjunto, se prqpuseramencontrar al temativas à simples regeneração natural do mato, de modo a rentabilizar, de novo, as vastos espaços com aptidão florestal de que a Freguesia dispõe e que os incêndios florestais, na ausência de vontade política para desenvolver e pôr em prática uma "nova floresta", condenaram a ficar de mato.

Projectos de mudança da "política de terra queimada"

As vertentes das serra do Açor constituem uma área repulsiva à fixação de população e, por conseguinte, também à de investimentos que permitam aproveitar as suas pacas potencialidades.

No entanto, contrariandb o habitual "deixa andar" inerente a estas situações, Associação de compartes e Junta de Freguesia do Pióoão, emperfeita sintonia, uniram esforços, o que é muito raro, no sentido de tirar partidb das qportunidades que a serra oferece e lançaram mãos à obra, através do desenvolvimento de alguns projectos diferentes mas complementares, na óptica de fixação da população, e de tomar mais atractivo e rentável toob este espaço que oferecem acsvisitates.

O projecto em execução, desenvolvido pelo arquitecto PedroDias, visa reaperar, reconstuirr, reciclar e reocupar a aldeia histórica do Piócão, promovendb o emprego, incentivando a fixação da população jovem e estimulando a agricultura e a produção local de produtos endógenos.

A proposta assenta na criação de um trajecto paisagístico e pedagógico ena instalação de um capril, unaqueijaria, umanfiteatroao ar livre, jarcimcenuúnas, jardim das aromáticas e loja da aldeia, para comercializar os prodtos tradicionais.

Deste modo, considerando que a pastorícia é, no dizer do Presidente da Associação "uma ferramenta que, sendo bem aproveitada, pode evitar muitas catástrofes" e, além disso, também é excelente para a redução dos combustíveis correspondentes ao estrato arbustivo, este foi umdos primeiros dojectivos a ser concretizadb, através da construção de um ovil (fot. 10) , no Tomo, com capacidade para 100 ovelhas, e reabilitação de antigos socalcos para pastagem (fot. 11) e de um capril, no Pióoấo (fot. 12) , para 400 cabeças, cuja área envolvente está organizada em parques de pastoreio.
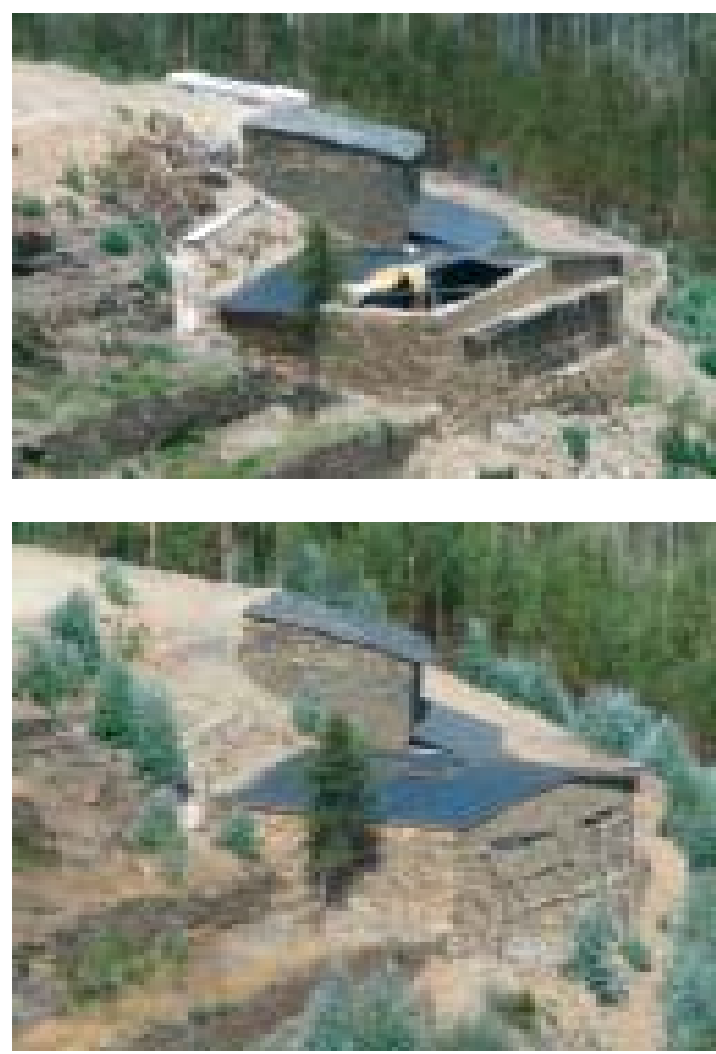

Fot. 10-A e B - Ovil do Torno. Em cima, em Maio de 2009, após ter sido destelhado por vendaval e, em baixo, em Setembro, depois da reposição da cobertura.

Fonte: Associação de Compartes da Freguesia do Piódão.

Não cabe aqui desenvolver todas as oportunidades que se abrem com estas iniciativas, mas, desde logo, a instalação da subsequente queijaria, atro projecto em arso, já a funcionar numa fase experimental, não só permitiu a recuperação de outro espaço degradado, mas também voltou a dar vióa à cantina da antiga escola primária. A posterior abertura da loja da aldeia dará nova vitalidade e valorização aos produtos tradicionais, como é o caso da aguardente de medronho, e abre portas à 

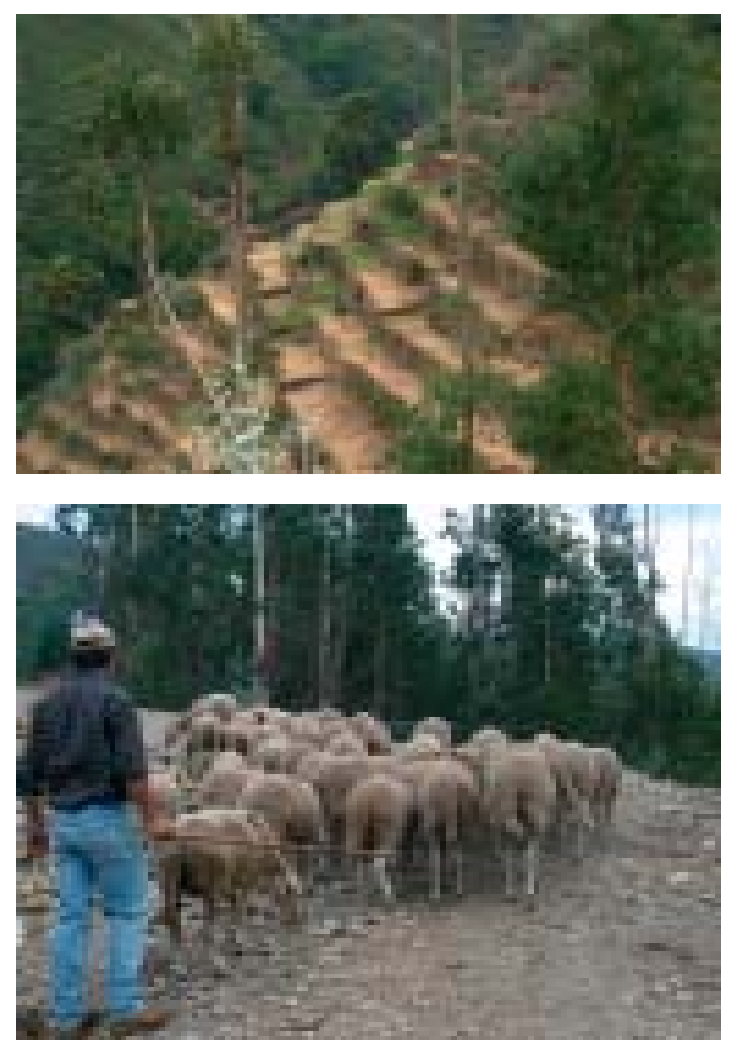

Fot. 11-A e B - Tomo. Em cima, socalcos depois da intervenção do corte do mato que os cobria, com vista a serem transformados em pastagem. Em baixo, pormenor do rebanho a dirigir-se para a área de pasto.

Fonte: Associação de Compartes da Freguesia do Piódão.
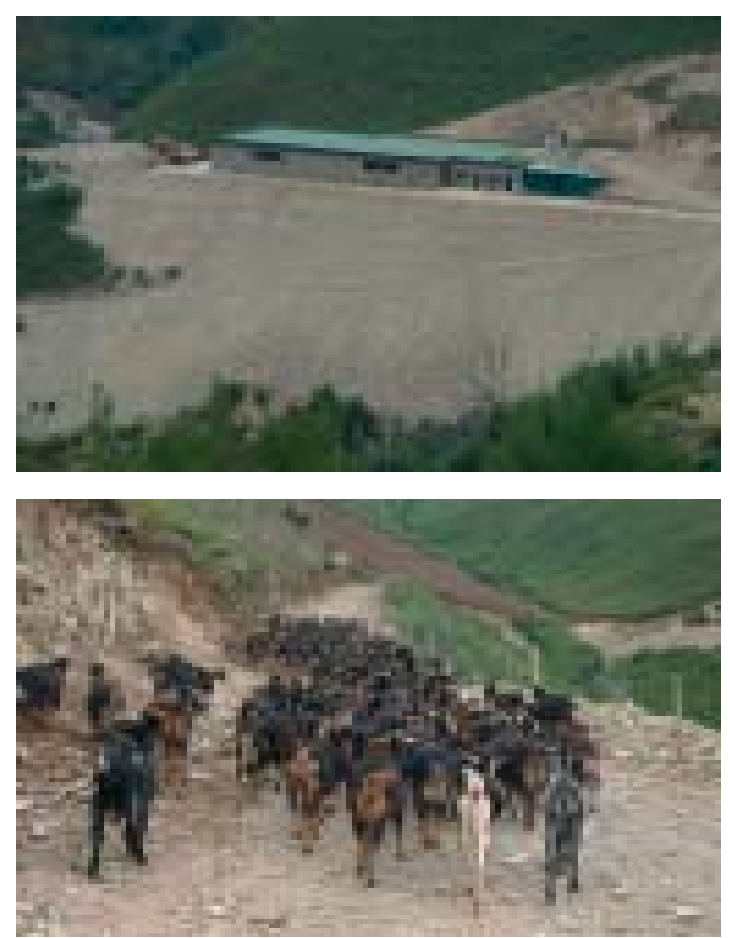

Fot. 12-A e B - Capril do Piódão. Em cima, vista geral, e, em baixo, saída da "cabrada" para pastagem num dos parques da serra.

Fonte: Associação de Compartes da Freguesia do Piódão. concretização e viabilidade tanto das diversas iniciativas previstas, como de outras que se podem associar e desenvolver à volta deste projecto integrador.

i Percurso pedestre: Piódão - Penedo da Sombra - Piódão

Opercurso pedestre inicia-se na praça central da aldeia do Pióoấo e começa por ut i l izar o antigo caminho que era usado na ligação entres as aldeias do Pióoão e da Malhada Chã para as idas à missa, à escola e para transporte das mortos que, então, eram sepultados no cemitério do Piódão. Assim, depois de sair da aldeia, percorre cerca de 800m, por entre os socalcas a sul do Pióoão, prossegue até ao capril comnitário e, depois, continua a subir, pelo antigo caminho, até que inflecte para nascente, em direcção ao Penedo da Sombra, donde se desfruta uma paisagem magnífica. Depois, continua para Norte, até iniciar a descida de regresso ao largo central do Pióoão, feita no sentido de poente, através db velho caminhouti 7 izadopelos antigos aldeões para aceder aas baldios.

Toob o trajecto do percurso foi intervencionado, no sentido de se mel horar a acessibil idade e, assim, garantir maior conforto e segurança aos pedestrianistas, bem como no de facultar informaçães úteis aas visitantes, através da colocação, em sítios estratégicos, de diversos painéis informativos relativos à importância do local, tais como o explicativo do perarrso pedestre, ou os relativos à aldeia histórica do Piódão e à estrada real, ou aos prados cimeiros (com referência aos baldios e ao carvão) e à eira comnitária, contendo indicações sobre o centeio, a malha e arte nupestre (fot. 13) .

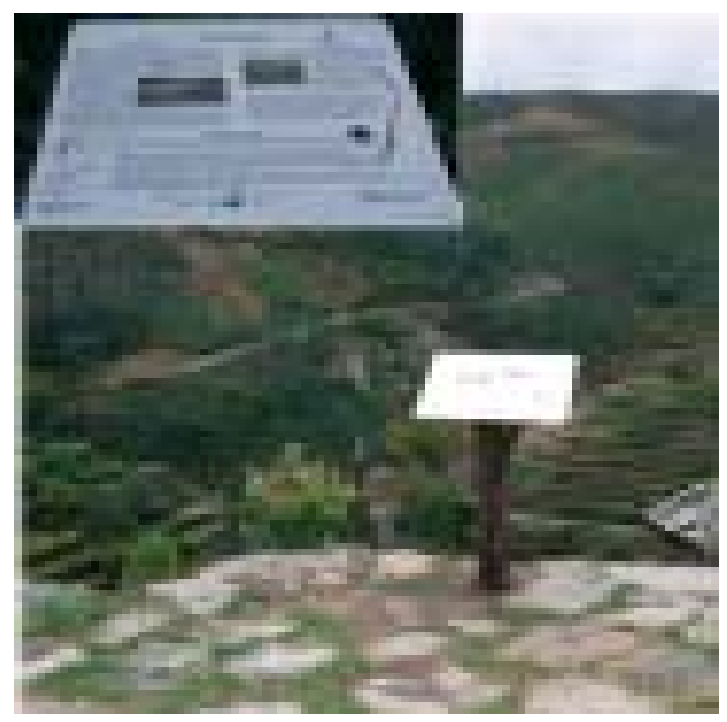

Fot. 13 - Vista sobre o Melhadinho (Estalagem, Escolas, Capela) tamada desde a eira comunitária sobranceira ao Piódão e, em cartela, pormenor do respectivo painel de sinalização.

Fonte: Associação de Compartes da Freguesia do Piódão. 
i Centro Interpretativo da Aguardente de Medronho

o Centro visa desenvolver novos modelos na produção de aguardente de medronho, aproveitando o conhecimento tradicional, baseado num saber-fazer ancestral, de forma a transmitir esse conhecimento e preservar este legado para as gerações vindouras.

Assim, a par da produção da aguardente de medronho de acordo com a tradição, o Centro (fot. 14) tem também fins pedagógicas, estando dispanível para receber visitas de grupos das escolas, especialmente da região.
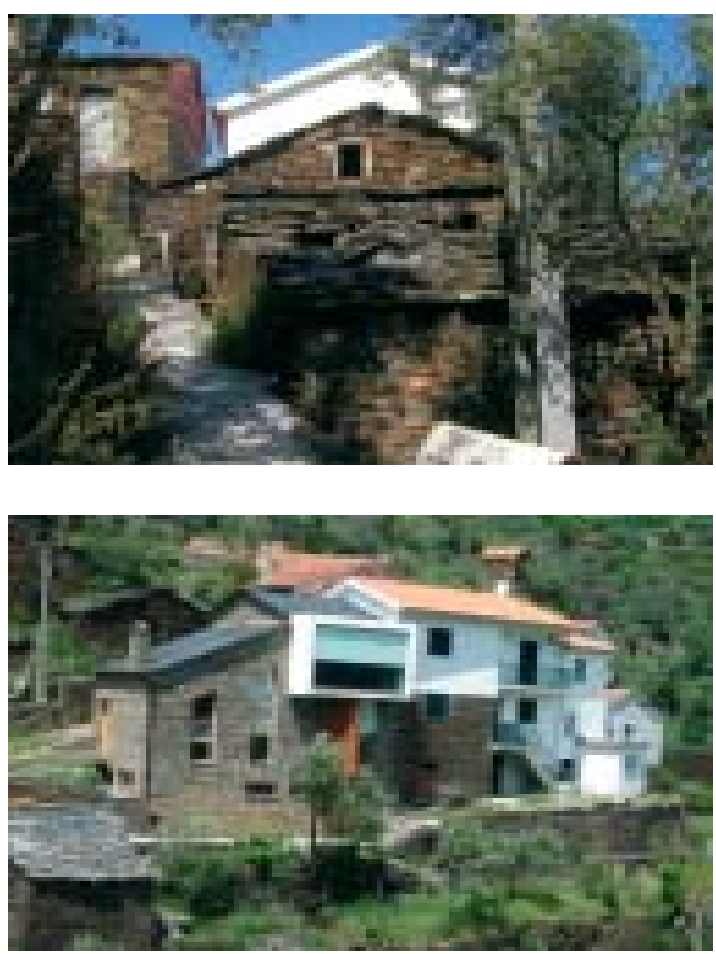

Tot. 14-A e B - Vista geral do CIAM, antes e depois das doras de reabilitação.

Fonte: Associação de Compartes da Freguesia do Piódão.

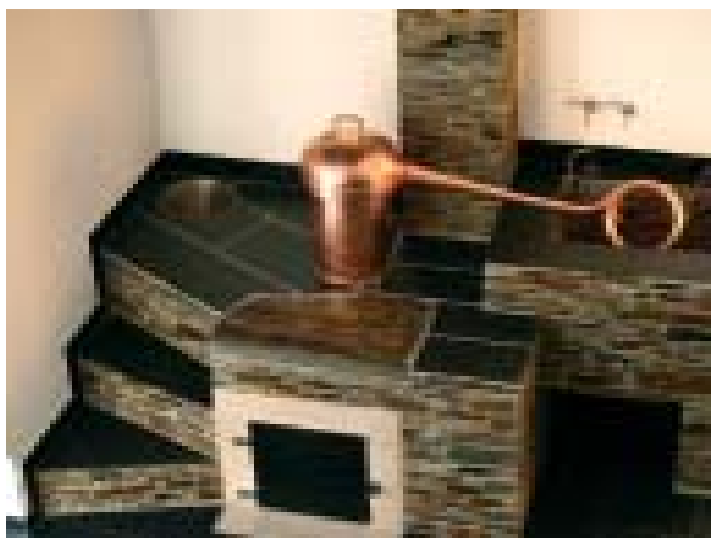

Fot. 15 - Aspecto de pormenor do alambique instalado no interior do CIAM.

Fonte: Associação de Compartes da Freguesia do Piódão.
Nesta conformidade, o alambique, com uma configuração análoga aos tradicionalmente usados no Pióoâo, foi instalado no mesmo local ande, durante anos, se produziu aguardente de medronho (fot. 15) .

\section{Anteriores projectos de valorização db patrimánio}

Inseridas nesta lógica de mudança de atitudes e numa estratégia de valorização do vasto patrimánio (natural, edificadb, altural,...) foram desenvolvidas vários projectos, de que, numa breve referência, damos a conhecer três dos mais significativos.

i Tritho pedestre: Piódão - Foz de Égua - Chãs de Égua - Piodão

O percurso pedestre une algumas das pequenas aldeias e quintas das magníficos vales das ribeiras do Piódão e das Chãs de Égua.

Desenvolve-se emmateriais xistosos, sendo, por vezes, dorigado a vencer declives algo acentuados, percorrendo antigas campos agrícolas, muitos deles abandonados e preenchidos por vegetação arbust iva. A água é uma constante ao longo de toob o percurso, bem identificado e com recantos fantásticos, que entusiasmam toolos quantos o percorrem, no seu todo ou, apenas, emparte.

\section{i Centro de Interpretação de Arte Rupestre}

o centro foi instalado na antiga escola primária e apresenta uma síntese da arte rupestre esculpida nas rochas das vertentes do vale da ribeira de chãs de Égua que, no dizer de Paulo Ramalho, coordenador do projecto, constitui "um dos mais importantes santuários portugueses de arte nupestre atriburivel ao período Neolítico e Idade do Bronze, entre o III e o I miléniosa.c.".

Pela sua importância histórica, mas tambémpela deslunbrante vista que dele se desfnuta sdore a paisagem ciraundante, este centro bemmerece una visita.

\section{in. Museu (Núcleo museológico) do Piódão}

O museu do Piódão encontra-se instalado à entrada da aldeia, no Largo do Cónego Manuel Fernandes Nogueira, e constitui uma extensão do Museu Etnográfico de Arganil.

Pretende retratar algumas das belezas naturais da serra e ser uma espécie de mostra da memória colectiva da freguesia de Piódão, recordando as dificuldades da vida de antanho por aquelas remotas paragens da Serra do Açor.

Conta com diversas peças antigas cedidas por muitos habitantes e naturais de Pióoão e encontra-se 
divididb em três áreas tenáticas: "Oolhar dos autros", "Tra história dheia de estórias" e "Vida quotidiana" . De entre as peças expostas, duas assumem particular significado. São elas o aercoínamo que, no início dos anos 60, levou, pela primeira vez, a luz eléctrica ao Piódão e uma réplica da antiga Estrada Real, que se desenvolvia pelas cumeadas da serra do Açor, hoje praticamente destruída.

Reabilitação da rede viária e parque de estacionamento do Piódão

Decorridos mais de três anos sobre os acontecimentos erosivos, algumas das infra-estnuturas rodoviárias afectadas, designadamente, nas imediações do Piódão, como a Estrada Formarigo (cruzamento da EN 344) - Penedos Altos - Piódão, com cerca de $15 \mathrm{Km}$ de extensão, ou o parque de estacionamento do Pióoão (fig. 8) e os acessos à Foz de Égua, tanto via Torno como via Chãs de Égua, foram recuperadas e formalmente inauguradas no dia 2 de Setembro de 2009, num investimento que rondou cerca de dois mi lhões de euros.

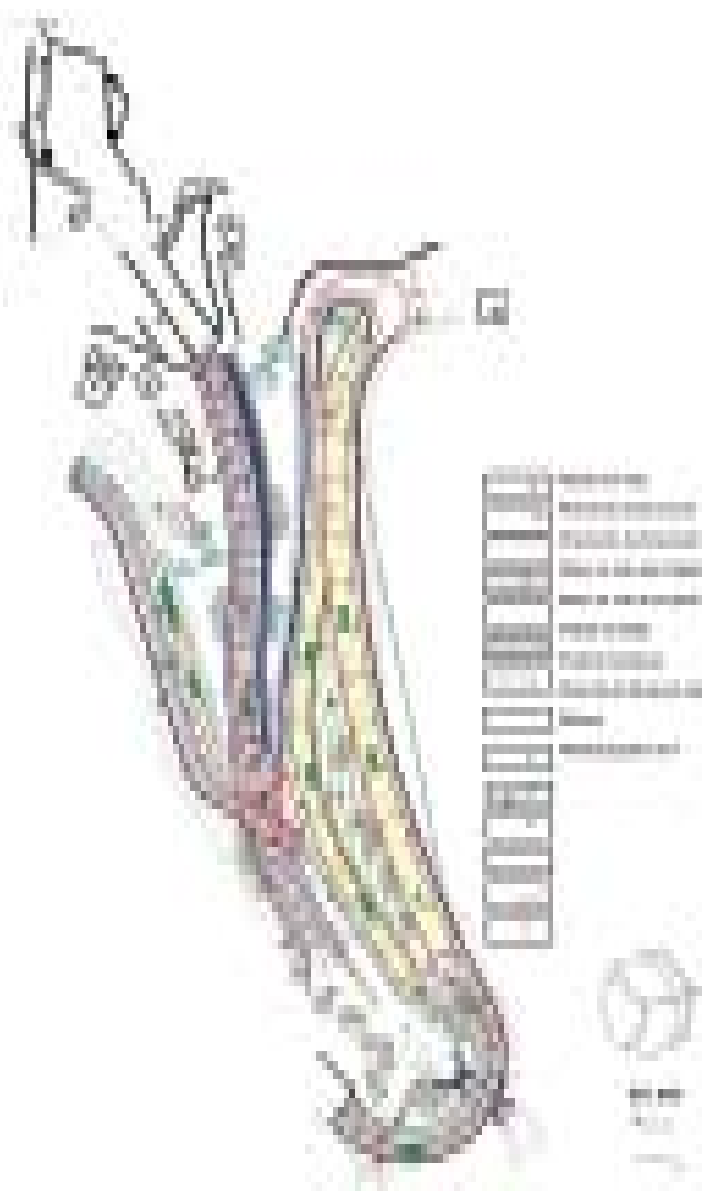

Fig. 8 - Planta da área a requalificar no Piódão. Fonte: Câmara Municipal de Arganil.
Estas obras, ainda não estão completamente concluŕcas, pois falta colocar as "rails" de protecção na estrada e recuperar a área da piscina. Contudo, a requalificação do espaço ribeirinho ganhou em sentido estético, com valorização do xisto e, sobretudb, em funcionalidade, tanto com a ribeira a correr, denovo, a céu abento (fot. 16) , como en termos de descongestionamento do trânsito (fot. 17) .

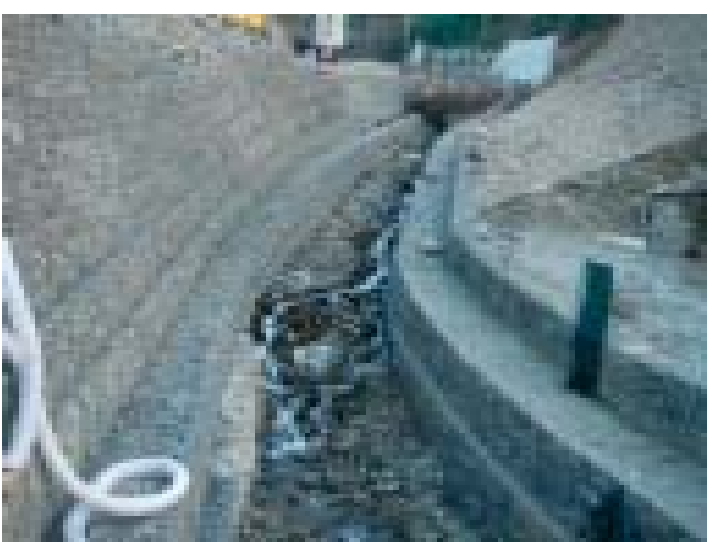

Fot. 16 - Pormenor da execução das obras na área do antigo parque de estacionamento. Fot. : Eng. ${ }^{a}$ Carla Neves, Câm. Mun. Arganil.

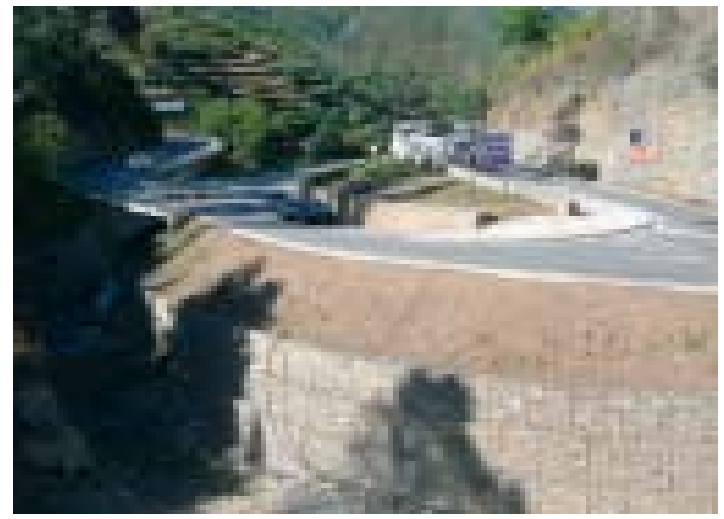

Fot. 17 - Vista parcial da área ribeirinha já requal ificada.

Recuperação de piscinas e praias fluviais mais danificadas

A reconstrução de algumas destas infra-estnuturas foi complicada, mormente nalgumas situações do concelho de Arganil, onde a entrada de máquinas não foi possível ar esteve cifiarltada pela inexistência de caminhos de acesso.

No entanto, conciliando o esforço desenvolvido pela Câmara Municipal, com a boa vontade e colaboração das respectivas Comissões de Melhoramentos, foi passível recuperar todas estas infra-estruturas, com excepção da já mencicnada no Pióoão. Vejamos, a título de exemplo, alguns aspectos dessas reabil itações. 
i. O imprescindível papel das Comissões de Melhoramentos

A importância das Comissões de Melhoramentos na melhoria das condições de vida das populações serranas é, desde há muito, conhecida. E, mais uma vez, o dinamismo das respectivas Direcções foi fundamental para a reabi litação das piscinas fluviais mais inacessíveis, concretamente as no Soito da Ruiva e no Sobral Magro.

\section{Soito da Ruiva}

Tendb en conta a local ização desta piscina fluvial (fot. 18) , pois, de entre todas as afectadas, é aquela que se encontra mais afastada de qualquer via rodoviária, a sua reabilitação parecia quase impossível, qpinião al iás part i lhada por Teresa Neves, Presidente da Comissão de Melhoramentos ${ }^{2}$.

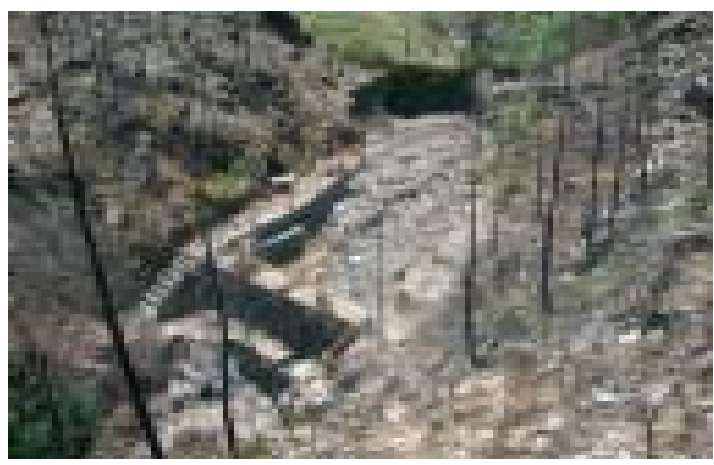

Fot. 18 - Aspecto da piscina fluvial do Soito da Ruiva, depois da enxurrada (22 de Junho de 2006) .

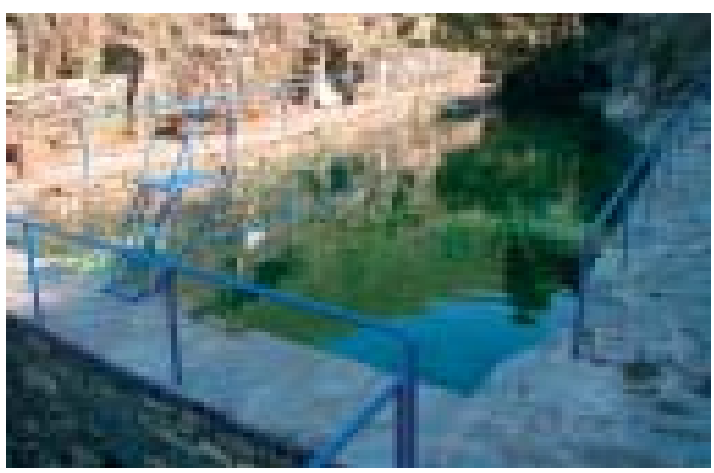

Fot. 19 - Aspecto da piscina, após a recuperação efectuada cerca de três anos depois (16 de Julho de 2009) . Fonte: http://blog. soitodaruiva. com/?pg=viewPost\&id=94
Assim, a direcção da Comissão decidiu resolver o problema. Para isso organizau, nos dias 1, 2 e 3 de Maio de 2009, uma excursão com as naturais e amigas do Soito da Ruiva residentes em Almada e Lisboa, cerca de 60 pessoas, que, com grande entusiasmo, deitaram mãos à obra e deixaram a reabilitação quase pronta.

Mas, como não conseguiram terminar o trabalho, decidiram concluŕ-lo no fim de semana de 23 e 24 de Maio. Assim, no dia 22, sexta feira, pelas $20 \mathrm{~h} 00$ (depois de todos saírem do trabalho) rumaram ao Soito da Ruiva ${ }^{3}$ para terminarem a obra antes iniciada (fot. 19).

\section{Sobral Magro}

Após a real ização das doras de restauro das muros laterais da piscina fluvial, programadas pela Direcção da Comissão de Melhoramentos do Sobral Magro, e a remoção de pedras db leito da represa (fot. 20) ., deu-se início, no dia 27 de Junho de 2009, ao enchimento da piscina e as doras de arranjo da área envolvente (fot. 21) , que ficaram concluídas no início do mês de Jillh.

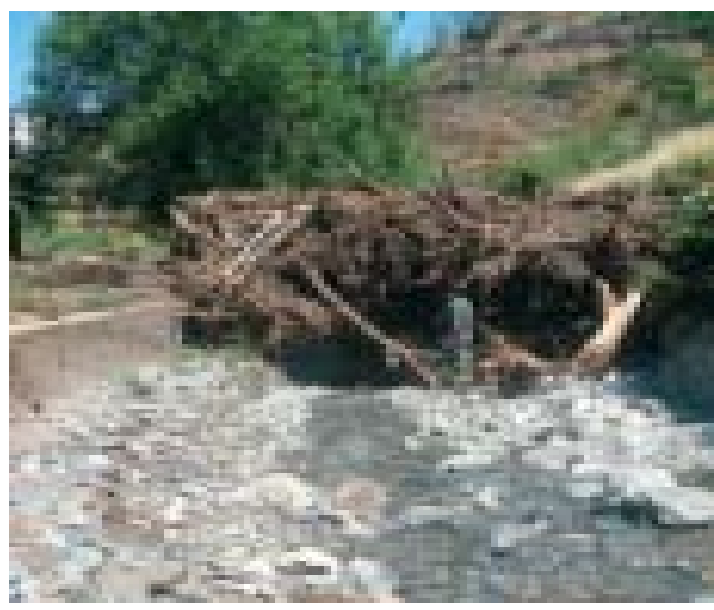

Fot. 20 - Aspecto da piscina fluvial do Sobral Magro, depois da enxurrada (22 de Junho de 2006) .

Dois belos exemplos de como o trabalho voluntário, quando devidamente enquadrado e coordenado, pode dar excelentes resultados, com baixo custo. Pena é que as responsáveis deste país não apoiem mais estas colectividades que tanto têm feito (e, estou certo, irão continuar a fazer) pelo

"Apesar dos vários apelos à autarquia e depois de analisado o espaço pelo engenheiro Ricardo Dias, responsável da câmara Municipal de Arganil pelas doras públicas, concluiu-se que a única forma de recuperar o espaço implicaria a abertura de uma estrada até ao local, para possibil itar a entrada de um equipamento (retroescavadora) . Conhecendo estes processos de abertura de estradas, perdemos umpouco a esperança de ver recuperadb o local, pois, na verdade para além dbs rearsos da autarquia serem poucos, é difícil as pessoas cederem as suas propriedades" .

"Sendo assim, pensámos em reunir um grupo de pessoas e, num fim de semana, tentar a limpeza da piscina. .. Parecia utópico, mas, na verdade, conseguimos fazê-lo no mês de Maio passado \{uww.soitodanuiva.com\} e, com o traballho efecturadb, sentimo-nos orgulhosas das nossas gentes" e, não é caso para menos! "Chegámos já depois da meia-noite e... "toca a dormir" porque a sineta toca cedb. Às 8h00 da manhã, na Regadinha, já a azáfama era de tal ordem que nenhum pássaro se atrevia a pausar no local. Nb Sábadb, ao final do dia, demos o traballo como terminadb e o ar de satisfação era visível em todas as rostos presentes. Forram dbis fins de semana de intenso trabalho, ao qual a maioria de nós não está habituada. As nossas actividades profissicnais são bem diferentes deste tipo de trabalho, mas o empenho e a vontade de voltar a ver preservadb um local construídb pelos nossos antepassadas e anteriores direcções da aMsR que nos merecem toob o respeito, deu-nos força para continuar até ao fim." \{http://blog.soitodanuiva.com/?pg=viewEost\&id=69 \}. 
desenvolvimento do interior e, sobretudb, não sejam envolvidas, de corpo e alma, em programas que, permitindo aproveitar os fundos comunitários colocados à nossa disposição, poderiam criar melhores condições de vida para os, ainda, residentes e, ao mesmo tempo, tornar mais atractivos estes lugares, quanto mais não seja para neles podermos passar uns dias por ano, ou simplesmente, para aqueles que, de passagem, as visitam.

\section{i A inevitárel intervenção das Câmaras Mnicipais}

Os serviças municipais de Protecção Civil, pela sua maior proximidade às populações, constituem o primeiro escalão de actuação em qualquer um dos três pilares em que assenta o sistema de protecção civil: prevenção, socorro e reabi i itação.

Não será, pois, de admirar que, em situação de acidente grave e catástrofe, as populações tentem obter ajuda para a resolução dos seus problemas, junto das respectivas Câmaras Municipais, como, aliás, sucedeu nestes casas. Mas, nem sempre, como vimos nas duas situações anteriores, foi possível dar

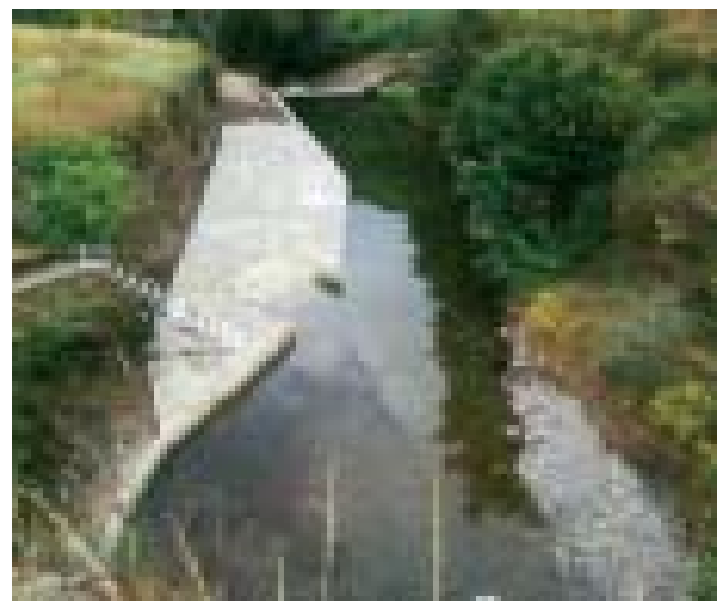

Fot. 21 - Aspecto actual da piscina, após a reabilitação realizada três anos depois (27 de Junho de 2009) .

Fot. : Ana T. Domingos \{http://sobralmagro.blogspot.com/\}

total resposta aos anseios da população.

No entanto, autras have em que tal foi possível, como também já vimos a propósito do Piódão (Arganil) . Agora, a título de exemplo, apresentamos autras duas situações, ajas infra-estnuturas foram bastante danificadas pelas enxurradas e que se localizam, respectivamente, nos concelhas de Seia e de Oliveira do Hospital.

\section{Apiscina fluvial da Vide (Seia), no rioAlvoco}

Porque já estava preparada para a época balnear que se aproximava, com as comportas colocadas no açude, para fazer a retenção da água, foi uma das piscinas fluviais coma estnutura mais danificada pela cheia de 16 de Junho de 2006, dado que a de 14 de Jilho já transportaumenos material (fot. 22) .

Para reabil itar aquele espaço houve necessidade de demol ir toda a estrutura e const nuir uma nova, com soluções independentes para a travessia dos peões (pontão) e para a retenção de água (açude) para a piscina (fct. 23) . Estanova infra-estnutura permitemaior faci lidade tanto à ciraulação do caudal líquido, como ao transporte da carga sólida, mesmo com as comportas colocadas, uma vez que o escoamento está mais faci litado do que na situação anterior, na medida em que o açude passa a funcionar como se fosse um descarregador de superfície duma barragem, sem grandes dostáculos a dificultarem a sua transposição.
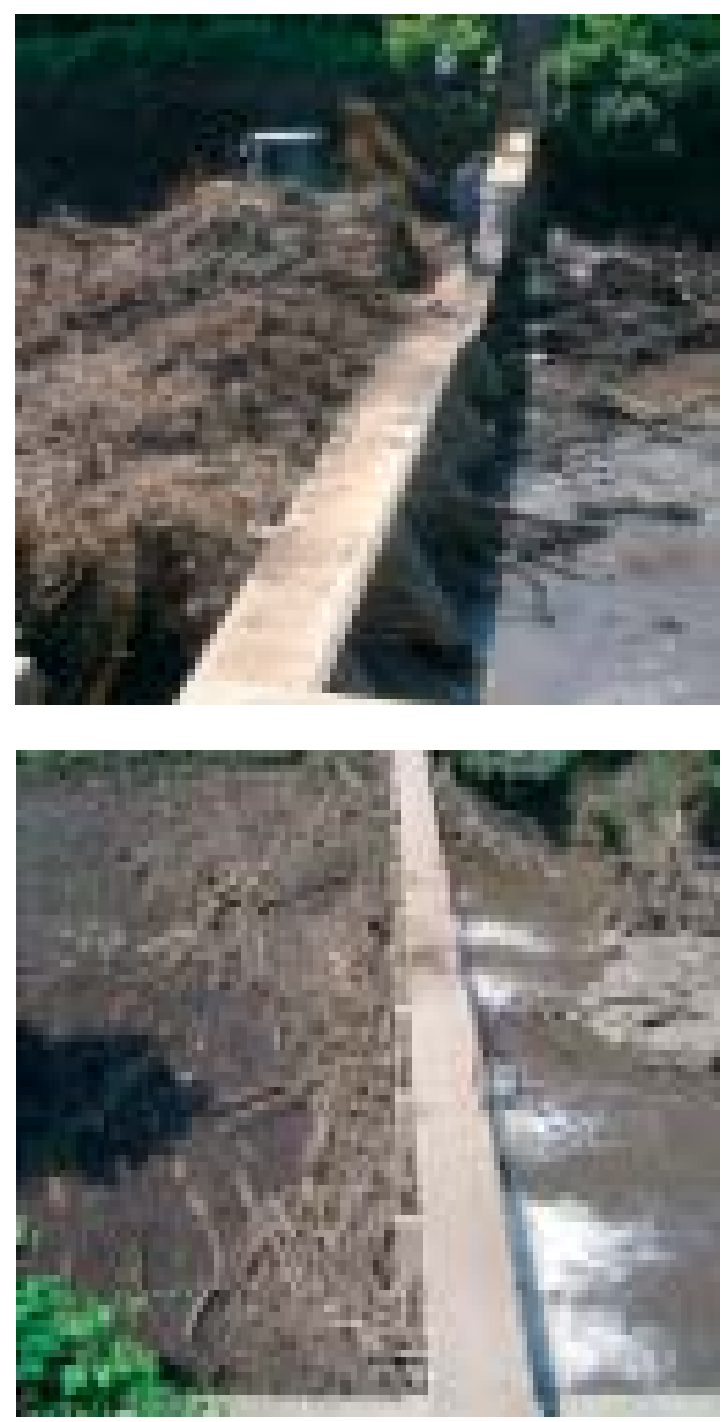

Fot. 22-A e B - Em cima, aspecto da remoção do material acumulado junto do pontão-açude da Vide (em 22 de Junho de 2006) e, em baixo, pormenor da acumulação de material, depois da segunda enxurrada (em 15 de Julho de 2006) . 


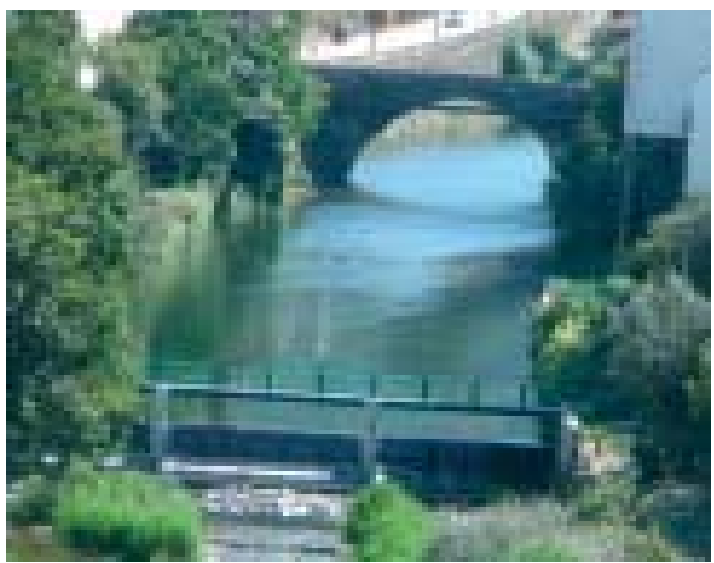

Fot. 23-A - Vista geral da piscina fluvial da Vide, após as obras recuperação (06 de Setembro de 2009) .

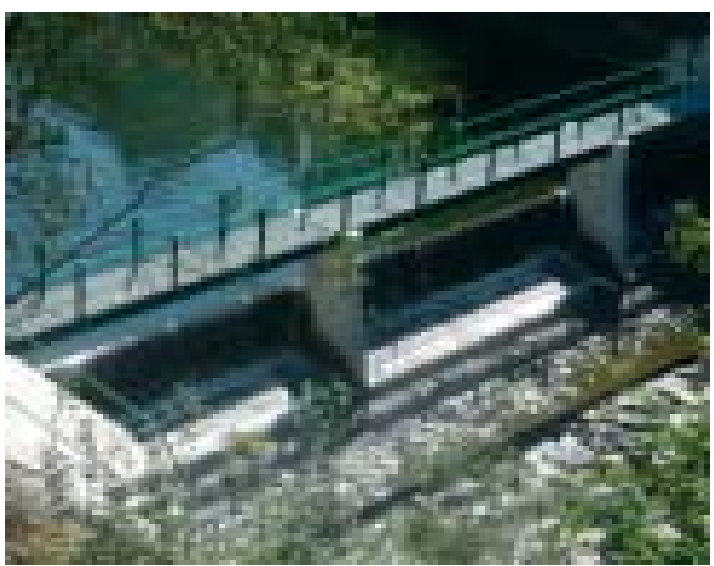

Fot. 23-B - Pormenor da nova solução adoptada, pontão e açude independentes. (06 de Setembro de 2009)

\section{Apraia fluvial de Avô (Oliveira do Hospital) , no rioAlva}

Esta praia fluvial, porventura, por ser a área balnear do concelho com as melhores infra-estruturas, tem merecido atenção e cuidado muito especial por parte da autarquia.

Assim, a intervenção anteriormente mencionada, realizada na sequência do temporal de 1988, dbtau-a de algumas melhorias que a tomaram num espaço de lazer agradável e que, sobretudb com a requal ificação concluída em 2004, altura em que o município nela investiu cerca 600 mil euros, passou a ser um espaço extremamente procurado, até que, em 16 de Junho de 2005, a situação de 1988 se repetiu (N. Preira e L. Lafenç, 2007), ainda que com menos gravidade.

Assim, de imediato houve preocupação em remover os materiais abandonados na praia, essencialmente constituídos por restos de árvores, e, também, em proceder à limpeza do leito, através da sua lavagem, para remoção da cinza aí acumulada (fot. 24) .

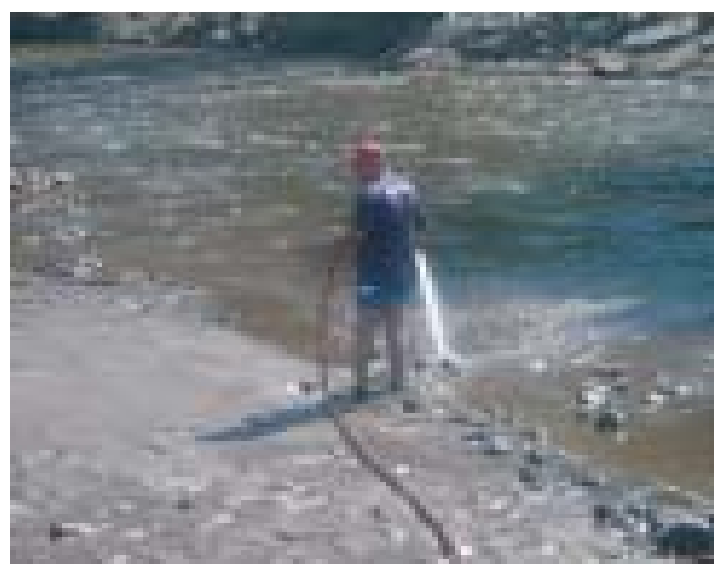

Fot. 24 - Aspecto da lavagem do leito do rio Alva, na praia fluvial de Avô, com vista à remoção da cinza nele depositada (22 de Junho de 2006) .

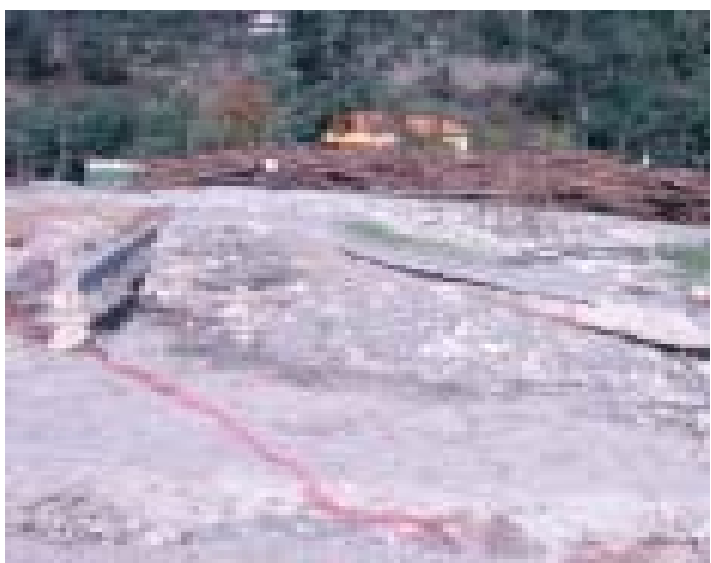

Fot. 25 - Detalhe da praia fluvial de Avô, após a destruição dos arruamentos e a deposição dos materiais abandonados. A figura

humana e a casa servem de escala (16 de Julho de 2006) .

Com tudo já em ordem para iniciar mais uma época balnear, uma nova enxurrada, desta vez a 14 de Julho, veio provocar grande acumulação de troncos e danos avultados na infra-estrutura, designadamente em termos do pavimento dos arruamentos (fot. 25), deixando-a "imprópria para banhos", una vez que esta cheia foi muito mais potente e devastadora do que a anterior.

Assim, depois dos estragos provocados pelas grandes cheias de 2006 (Primavera, Verão e attono) , a praia fluvial de Avô entrou de novo em doras e nesta reabilitação foram investidos cerca de 150 mil euros, o que denota bem o empenho posto pela autarquia na sua reaperação (fot.s. 26 e27).

Estes exemplos de reabilitação, pese a sua importância, quer em termos de qualidade de vida, quer pelos montantes envolvidos, não passam, no entanto, de recuperações pontuais do muito que haveria a requal ificar depois dos incêndios florestais. 


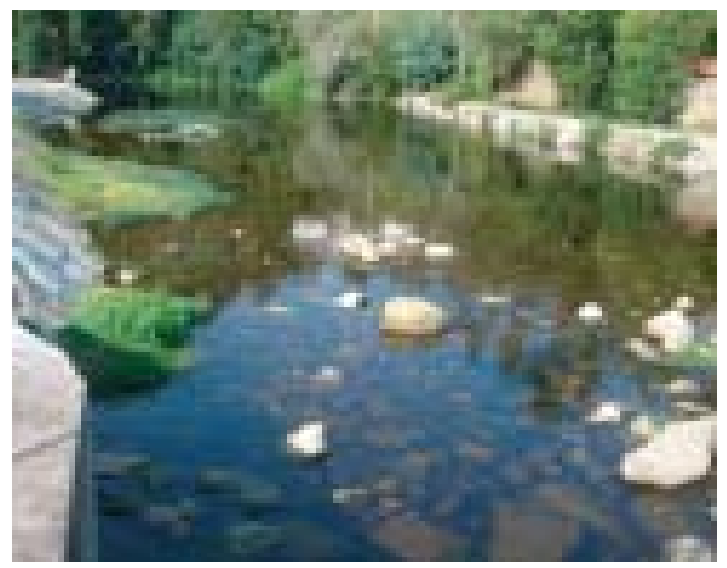

Fot. 26 - Aspecto actual do leito do rio Alva, na praia fluvial de Avô, após remoção da cinza (12 de Setembro de 2009) .

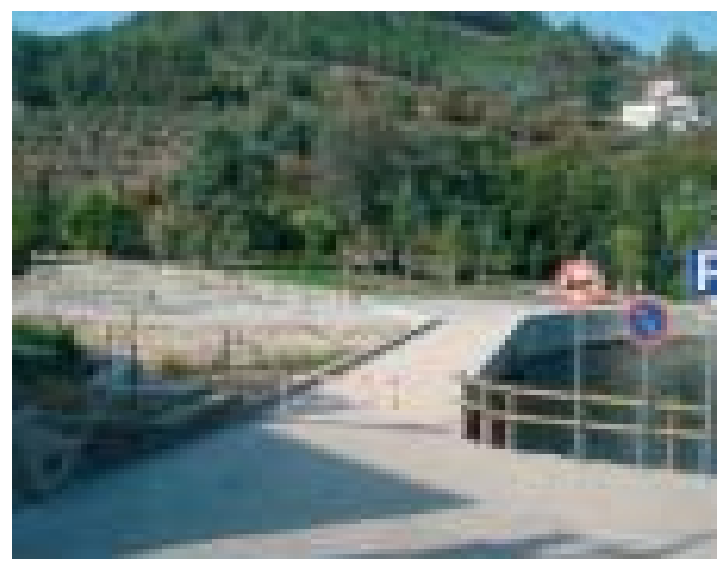

Fot. 27 - Vista da entrada da ilha do Picoto, na praia fluvial de Avô, após a reabilititação da área visível na fot. 25 (12 de Setembro de 2009) .

\section{Conclusão}

Ainda que este trabalho não corresponda a uma investigação de carácter marcadamente técnico, ligado à segurança e fiabilidade das infra-estnuturas apresentadas, ele denota autras preocupações e não deixa de abordar a problemática dos riscos, em particular, num dos aspectos menos divulgado da sua manifestação, o qual tema ver com a reabi litação das áreas afectadas.

Deste modo, tomando como exemplo a manifestação do risco de incêndio florestal, apresentaram-se algumas situações, seleccionadas de entre aquelas em que houve reabilitação de infraestruturas, mais concretamente, residências familiares.

No entanto, o maior destaque foi dado às que foram danificadas em sequência da manifestação do risco de erosão após incêndio florestal, uma vez que este tipo de risco é menos conhecido, quer por se manifestar algum tempo depois das incêndios, quer por raramente lhe ser atribuída importância.
Indicaram-se, pois, algumas reabilitaçães de infraestruturas efectuadas tanto pelas Câmaras Municipais, directamente ou com apoio do Govemo Central, por serem as entidades que detêm essa responsabilidade, mas também se deram exemplos de como o trabalho voluntário pode contribuir para essa reabil itação, sobretudo quando aquelas entidades têm dificuldade emencontrar soluçães exequíveis, pelo que se conclui pela vantagem do envolvimento de diferentes organizaçães da sociedade civil, na requperação das áreas afectadas por catástrofes.

Por último e ainda que ao de leve, não deixaram de se mencionar as situações mais habituais, que correspondem àquelas em que não houve qualquer reabil itação das áreas ardidas ou qualquer tipo de recuperação das áreas que, nas vertentes ou ao longo das principais linhas de água, foram erosionadas ou sofreram deposição de materiais.

\section{Agradecimento}

O autor agradece a todos aqueles que, de alguma forma, colaboraram com o trabalho de investigação que, ao longo de vários anos, tem vinob a desenvolver na serra do Açor, designadamente às diversas entidades que contribuíram para a sua viabilização e, em particular, para a redacção deste texto, designadamente à Câmara Municipal de Arganil, na pessoa do seu Presidente, Eng. ${ }^{\circ}$ Ricardo Alves e, também, da Eng. a Carla Neves, responsável pelo acompanhamento da obra de requalificação do espaço envolvente do Piódão, bem como aos senhores Francisco Fontinha, Presidente da Associação de Compartes da Freguesia do Piódão, e José da Conceição Lopes, Presidente da Junta de Freguesia do Piódão, pelas valiosas informações que nos prestaram e pela disponibilidade com que nos acompanharam em muitos dos reconhecimentos de campo que efectuámos.

À D. ${ }^{2}$ Teresa Neves, Presidente da Comissão de Melhoramentos do Soita da Ruiva, estamos gratos pela franca receptividade na disponibilização de informação scbre a reabil litação da piscina fluvial.

Agradecemos também a todos os outros, e muitos foram, que, não sendo aqui especificamente mencionados, anonimamente, nos prestaram diversas informaçães e esclarecimentos, colaborando deste modo, para a investigação realizada.

A toobs, onosso bem-haja, tão àmoda dabeira-serra. 


\section{Referências bibliográficas}

Obras Impressas:

Ctra, P. Proença (2002) - "Vulnerabilidade e risco resultante da ocupação de uma planície aluvial o exemplo das cheias do rio Mondego (Portugal central) , no Invemo de 2000/2001". Territorium, Revista de Geografia Física Aplicada no Ordenamento do Território e Gestão de Riscos Naturais, Minerva, Coimbra, p. 13-36;

Diário do Govemo (1822) - n. ${ }^{\circ}$ 98, de 27 de Abril, p. 690-2;

DirecÇ̃̃o-Geral dos Recursos Naturais/Dimensão 6 (1988) - Aproveitamento Hidráulico do Vale do Mondego, Ministério do Planeamento e Administração do Território, Lisboa, s/p. ;

Fernandes, Carlos (2003) - "Primeiro o fogo e as cinzas. Agora as águas indonáveis" . Notícia de 1. a página, Jomal das Cortes, edição n. ${ }^{\circ} 193$, 9 de Dezembro, p. 1;

Fenanes, Carlos (2003) - "A erosão dos solos depois dos incêndios". Reportagem, Jomal das Cortes, edição n. ${ }^{\circ}$ 193, 9 de Dezembro, p. 5;

FialHo, José e Lourenço, Luciano (2007) "Precipitações intensas e prolongadas após incêndios florestais - O papel dos socalcos na erosão e deposição. Exemplos de bacias hidrográficas afluentes aos rios Alva e Alvoco (Serras do Açor e da Estrela) ", Riscos Ambientais e Formação de Professores (Actas das VI Jomadas Nacionais do Prosepe) , colectâneas Cindínicas VII, Faculdade de Letras da Universidade de Coimbra, p. 151-197 \{http://www.nicif.pt/ estudos:20cindinicas $\div 207 . h t m\}$;

Larnșo, Luciano (1988a) - Evolução de vertentes e erosão dos solos, nas serras de xisto do centro de Portugal, en consequência de incêndios florestais. Análise de casas dbservados em 1987. Relatório Técnico. Área: Incêndios Florestais, G.M.F. - I.F. 8805, reeditado em 2004, Riscos de Errasão após Incêndios Florestais, Colecção Estudos 52 e colectâneas Cindínicas V, Faculdade de Letras da Universidade de Coimbra, p. 13-32 \{http:// uww.nicif.pt/estudbs:20cindinicos $\% 205 . h \mathrm{ttm}\}$;

Laknșo, Luciano (1988b) - "Efeitos do temporal de 23 de Junho de 1988 na intensificação da erosão das vertentes afectadas pelo incêndio florestal de Arganil/Oliveira do Hospital" , Commicaçães e Conclusões, Seminário Técnico sobre Parques e Conservação da Natureza nos Países do Sul da Europa, Faro, p. 43-77, em Separata III Semana de Geografia Física, Coimbra, 1990, 35 p. e reeditado em 2004, Riscos de Erosão após Incêndios Florestais, Colecção Estudos 52 e
Colectâneas Cindínicas V, Faculdade de Letras da Universidade de Coimbra, p. 33-65 \{ www.nicif.pt/estudbs²0cindinicos:205.htm\};

Lourenşo, Luciano (1992) -"Aspects économiques, socia xet ailturels des incendies de forêt et de friche au Portugal". Actes du Seminaire sur la prévention des incenoties de forêts, I'anénagenent di temitoire et lespquilations. Atenas, p. 124-135; e, na versão portuguesa, "Aspectos socioeconómicos dos incêrotios florestais em Portugal", Biblos, Vol. IXVII, p. 373-385, reeditado em 2004, Mbnifestações do Risco Denotrocaustológico, Colecção Estudas 50 e colectâneas Cindínicas IV, Faculdade de Letras da Universidade de Coimbra, p. 29-43 \{http:// www.nicif.ptestudos:20cindinicos:204.htm\};

Lourenço, Luciano (1995) - "Efeitos erosivos observados em campos agrícolas das áreas montanhosas do Centro de Portugal na sequência de incêndios florestais". A Península Ibérica - um espaço em mutação, Actas, VI Colóquio Ibérico de Geografia, Porto, p. 999-1009 e reeditado em 2004, Manifestações do Risco Dendrocaustológico, Colecção Estudos 50 e colectâneas Cindínicas IV, Faculdade de Letras da Universidade de Coimbra, p. 79-92 \{http:// uww.nicif.pt/estudasะ20cindinicos:204.htm\};

Lourenş̧, Luciano (Coord.) (2006) - "2. Riscos Naturais", Paisagens de Socalcos e Riscos Naturais em Vales do Rio Alva, Colectâneas Cindínicas VI, Faculdade de Ietras da Universidade de Coimbra, p. 119-165 \{htto://www.nicif.pt/ estudas $\% 20$ cindinicos $\% 206 . \mathrm{htm}\}$;

Lourenço, Luciano e DireITo, A. Cunha (1994) "Arborização das vertentes serranas, uma medida de protecção contra as enxurradas. Fogos florestais um atentado contra as arborizaçães e um incentivo ao deservolvimento de enxurradas". Actas 2, Os rearsos Florestais no Desenvolvimento Rural, III Encontro Florestal Nacional, Figueira da Foz, p. 1-9. Versão resumida em Estrela Informação, 12, Manteigas, 1995, p. 21-22 e reeditado em 2004, Manifestações do Risco Dendrocaustológico, Colecção Estudos 50 e colectâneas Cindínicas IV, Faculdade de Letras da Universidade de Coimbra, p. 157-165 \{http:// www.nicif.pt/estudos`20cindinicos $\% 204 . h t m\}$;

Lourenç̧, Luciano e LoPes, N. Cunha (2004) "Incêndios Florestais, consequência e razão de ser de novas Mudanças Globais", GeoINova, Lisboa, n. ${ }^{\circ}$ "Ambiente e Mudanças Globais" , p. 45-64;

Mhruns, A. Femandes (1940) - O esfôrço do homem na bacia do Mondego. Ensaio geográfico. Coimbra, 299 p. ;

Ministério dAs ObRas PúblicAs - DirecÇÃo Geral dos 
SERVIçOS HIDRÁULICOS (1962) - Aproveitamento hidráulico do Rio Mondego, Vol. I. Síntese, Ministério das doras Públicas, Lisboa.

NAVE, Adriano e LourENço, Luciano (2007) 'Grandes incêndios florestais registados na área situada entre as superfícies alminantes das serras do Açor e da Estrela", Riscos Ambientais e Formação de Professores (Actas das VI Jomadas Nacionais do Prosepe) , colectâneas Cindínicas VII, Faculdade de Letras da Universidade de Coimbra, p. 95-121 \{http://www.nicif.pt/ estudas $\% 20$ cindinicas $\% 207 . \mathrm{htm}\}$;

PALRILHA, Paulo Marcos (2004) - As cheias do Mondego no ano hidrológico 2000/2001. Avaliação e percepção do risco de immdação. Dissertação de Mestrado, Universidade de Aveiro, 145p. (inéoito) ;

PerkIRA, Nuno e Larenço, Luciano (2007) - "Riscos de cheias e inundações após incêndios florestais. O exemplo das bacias hidrográficas das ribeiras do Piódão e de Pomares" , Riscos Ambientais e Formação de Professores (Actas das VI Jomadas Nacionais do Prosepe) , colectâneas Cindínicas VII, Faculdade de Letras da Universidade de Coimbra, p. 123-149 \{http://www.nicif.pt/ estudas $\% 20$ cindinicas $\% 207 . h t m\}$;

Pessoa, Rui Sá (2004) - "Os buracos do Vale Fermando". Notícia de 1. a página, Jomal das Cortes, edição n. ${ }^{\circ}$ 196, 8 de Março, p. 1;

PessoA, Rui Sá (2004) - "Vale Fernando avassalado pelas águas". Reportagem, Jornal das Cortes, edição n. 196, 8 de Março, p. 6;

Rнвн , Fermando (2003) - Riscos Naturais e Acção Antrópica. Estudos e Reflexões. Coimbra,

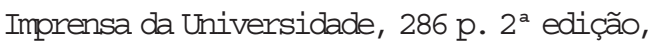
revista e aumentada.

SHVA, Carlos Alberto (2004) - "Após o fogo, a enxurrada". Imagens faladas, Jomal das Cortes, edição n. ${ }^{\circ}$ 196, 8 de Março, p. 9;

\section{Doamentas electrónicas disponíveis na intemet:}

http: //www. asbeiras.pt/?area=regiaocentro \&numero=16136\&ed=29062004

http: //www.asbeiras.pt/?area=coimbrasnumero $=41670$ \&ed $=19042007$

http: //www. asbeiras.pt/index.php?area=coimbra\& numero $=45787 \&$ ed $=04072007 \& \mathrm{vo}=1$

http: //www. asbeiras.pt/?area=coimbrasnumero $=72597 \&$ ed $=05062009 \% 5 \mathrm{C} \div 5 \mathrm{C} \div 5 \mathrm{C} \div 5 \mathrm{C}$

http://www.cgd.pt/Institucional/ResponsabilidadeSocial/Ambiente/Floresta-Caixa/AccoesFlorestacao/Pages/Piodao.aspx

http: //www. janelaazul .org/poa/o-centro-deinterpretacao-do-medronho http: //hww. janelaazul .org/poa/o-projecto-poa-nafreguesia-do-piodao?set language=pt

http: //www. janelaazul .org/poa/o-trilhointerpretativo

http: //www. janelaazul.org/poa/a-unidade-extensivade-pastoreio

http://hww.soitodanuiva.com/

http: //dafinitudedotempo.blogspot. com/2008/07/ centro-intenpretativo-da-arte-nupestre.html

http: //oacor.blogspot. com/2009/07/piscina-fluvialde-sobral-magro.html

http: / / ricaebelaserradoacor.blogspot.com/ 20081101 archive.html

http: ///blog. soitodanuiva. com/?pg=viewPosteid=65 http: //blog. soitodanuiva. com/?pg=viewPast\&id=69 http: //blog. soitodanuiva.com/?pg=viewPost\&id=71 http: //lolog. soitodaruiva. com/ ?pg=viewPast\&id=94 http: //lolog. soitodaruiva. com/?pg=viewPost\&id=109 http://sobralmagro.blogspot.com/ 